Contract No. 7405-eng-26

REACTOR CHEMISTRY DIVISION

THE CORROSION OF ALUMINUM ALLOYS IN HIGH-VELOCITY

WATER AT 170 TO $290^{\circ} \mathrm{C}$

J. L. English, L. Rice, and J. C. Griess

DATE ISSUED

SUA 159962

OAK RIDGE NATIONAL IABORATORY

Oak Ridge, Tennessee

operated by

UNION CARBIDE CORPORATION

for the

U. S. ATOMIC ENERGY COMMISSION 


\section{DISCLAIMER}

This report was prepared as an account of work sponsored by an agency of the United States Government. Neither the United States Government nor any agency Thereof, nor any of their employees, makes any warranty, express or implied, or assumes any legal liability or responsibility for the accuracy, completeness, or usefulness of any information, apparatus, product, or process disclosed, or represents that its use would not infringe privately owned rights. Reference herein to any specific commercial product, process, or service by trade name, trademark, manufacturer, or otherwise does not necessarily constitute or imply its endorsement, recommendation, or favoring by the United States Government or any agency thereof. The views and opinions of authors expressed herein do not necessarily state or reflect those of the United States Government or any agency thereof. 


\section{DISCLAIMER}

Portions of this document may be illegible in electronic image products. Images are produced from the best available original document. 


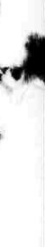


ABSTRACT .. . . . . . . . . . . . . . . . . . . . . . . . 1

INTRODUCTION . . . . . . . . . . . . . . . . . . . . . . 1

EXPERTMENTAL •. . . . . . . . . . . . . . . . . . . . 3

RESULTS . . . . . . . . . . . . . . . . . . . . . 6

Effect of Temperature and Flow Rate. . . . . . . . . . . . . . 6

Corrosion-Product Retention . . . . . . . . . . . . . 17

Effect of Time . . . . . . . . . . . . . . . . 18

1100 Aluminum . . . . . . . . . . . . . . 18

X8001 Aluminum . . . . . . . . . . . . . . . 19

Effect of Surface Finish and Pretreatment........... . . 23

The Corrosion Rate of Experimental Alloys . . . . . . . . . . 24

SUMMARY . . . . . . . . . . . . . . . . . . . 26

ACKNOWLEDGMENT . . . . . . . . . . . . . . . . . . . . 27

REFERENCES . . . . . . . . . . . . . . . . . . . . 27 


\title{
THE CORROSION OF ALUMINUM ALLOYS IN HIGH-VELOCITY
}

\author{
WATER AT 170 TO $290^{\circ} \mathrm{C}$
}

J. L. English, L. Rice, and J. C. Griess

\begin{abstract}
Short-term corrosion tests with types 1100, 5154, 6061, and $\mathrm{X} 8001$ aluminum alloys were conducted in water at flow rates ranging between 20 and 107 fps and at temperatures between 170 and $290^{\circ} \mathrm{C}$. Corrosion of the alloys was less dependent on flow rate in the range of 20 to $67 \mathrm{fps}$ than at higher velocities. At temperatures as high as $230^{\circ} \mathrm{C}$ no evidence of localized attack except for random shallow pitting was exhibited by these alloys, and all had comparable corrosion rates. At 260 and $290^{\circ} \mathrm{C}$ all alloys except $\mathrm{X} 8001$ showed extensive subsurface attack. At $260^{\circ} \mathrm{C}$ and at velocities up to $67 \mathrm{fps}$, the corrosion rate of $\mathrm{X} 800 \mathrm{l}$ aluminum was high during the early part of a run and then decreased to rates of between 5 and 15 mpy; at the highest velocity, the corrosion rate was constant at 200 mpy.

Tests with X8001 aluminum at $260^{\circ} \mathrm{C}$ showed that mechanically polished specimens corroded at about the same rate as those with a machine finish. A significant improvement in corrosion resistance at 20 to $67 \mathrm{fps}$ was accomplished, however, by exposing the specimens to water at 250 or $300^{\circ} \mathrm{C}$ in an autoclave for $24 \mathrm{hr}$ prior to exposure in the loop. At higher flow rates the pretreatment was ineffective.

Several experimental alloys containing various amounts of iron, nickel, and silicon were tested at 42 fps and $260^{\circ} \mathrm{C}$ for 10 days. Although the alloys contained different ratios of iron to nickel and some of the alloys had a very low silicon content, all corroded at the same rate and showed no improvement over X8001.
\end{abstract}

\section{INTRODUCTION}

The corrosion of aluminum and its alloys by high-temperature, flowing water has been the subject of a number of investigations for the purpose of determining the suitability of aluminum alloys as cladding for uranium-bearing fuel elements in power reactors. Tests have usually been conducted under conditions of moderate flow rate, 15 to $30 \mathrm{fps}$, and high temperature, 250 to $360^{\circ} \mathrm{C}$. For most reactors the rate of fuel burnup is such that fuel elements remain in a reactor for relatively long periods of time; consequently low corrosion rates must be achieved if thin aluminum cladding is to retain its integrity.

The results of previous investigations have shown that aluminum and most of the commercially available alloys suffer heavy corrosion damage in high-purity water at temperatures of $200^{\circ} \mathrm{C}$ and above. ${ }^{1,2}$ Alloying aluminum with many different elements has little, if any, effect in reducing the rate of attack. ${ }^{3}$ However, the addition of small amounts of nickel to aluminum substantially increases its 
corrosion resistance, and the addition of a small amount of iron to the above alloy produces a further beneficial effect. ${ }^{4}$ An alloy containing about $1 \%$ nickel and $0.5 \%$ iron is commercially available and is designated X8001. Recent data have shown that the presence of silicon in the alloy is detrimental to its corrosion resistance in high-temperature water, and by reducing the silicon content of the alloy to very low values a further lowering of the corrosion rate can be achieved. 5 The beneficial effect of the low silicon content, however, is only significant at temperatures of $300^{\circ} \mathrm{C}$ and above; ${ }^{6}$ in the range of $250^{\circ} \mathrm{C}$ all alloys of this class show comparable corrosion rates. The alloys with very low silicon content are not commercially available, and little or no data exist on their mechanical properties.

The corrosion tests described in this report were carried out as the first phase of a program to determine whether commercially available aluminum alloys could be used to clad fuel elements for the High-Flux Isotope Reactor which will be built at Oak Ridge National Laboratory to produce transplutonium elements. The details of the reactor have been presented in design reports. ${ }^{7,8}$ To achieve the high neutron fluxes necessary to produce significant amounts of the transplutonium elements, a small integral core which will operate at high power density and contain a flux trap will be used. Because of the very high power density, each fuel loading will last only about 10 days and corrosion rates considerably in excess of those suitable for conventional power reactors could be tolerated.

At the time the work to be reported here was started, two different types of fuel elements were considered. One type of fuel assembly consisted of a bundle of small-diameter tubes, the walls of which contained the fuel and the insides of which contained a twisted aluminum ribbon to produce swirl flow through the tubes. With this design, cooling-water flow rates in the range of $100 \mathrm{fps}$ would be required. The second type of assembly would be made up of thin, involute plates, and with this type, coolant-flow rates of about $40 \mathrm{fps}$ would be required to remove the heat. The latter type fuel assembly has since been selected, at least for the first few reactor loadings.

Light water will serve as the coolant for the reactor. The nominal water temperatures will be $49^{\circ} \mathrm{C}$ at the inlet and $88^{\circ} \mathrm{C}$ at the outlet of the reactor. However, because of the very high heat fluxes (as high as $1.5 \times 10^{6} \mathrm{Btu} / \mathrm{hr} \cdot \mathrm{ft}^{2}$ ) that will exist during reactor operation, relatively high aluminum temperatures will prevail. The aluminum temperature is further increased by the fact that corrosion products which adhere, at least partially, to the surface have low thermal conductivity. Since it has been shown that under conditions of heat transfer it is either the temperature at the oxide-metal interface or some mean temperature in the corrosion-product film that determines the corrosion rate, 9,10 meaningful isothermal tests must be conducted at temperatures expected to exist in the corrosion-product scale. Thus the tests described in this report were conducted in the temperature range of 170 to $290^{\circ} \mathrm{C}$, temperatures considerably higher than those of the bulk coolant.

Since data on the behavior of aluminum alloys in high-velocity water under conditions simulating those expected in the High-Flux Isotope Reactor did not exist, the experiments described in this report were necessary. Corrosion tests with aluminum specimens subjected to very high heat fluxes constitute another part of the program. The preliminary results from the heat-flux tests have a.lready been reported. ${ }^{11}$, 12 
EXPERTMENTAL

The greatest number of tests were carried out with types 1100, 5154, 6061, and $\mathrm{X} 8001$ aluminum; a few additional alloys were investigated less extensively. The compositions of the commercially available alloys that were tested are shown in Table 1 .

Table 1. Composition of Commercially Available Aluminum Alloy Test Materials

\begin{tabular}{|c|c|c|c|c|c|c|c|c|c|c|}
\hline \multirow{2}{*}{$\begin{array}{c}\text { Alloy } \\
\text { Designation }\end{array}$} & \multicolumn{10}{|c|}{ Composition* (wt \%) } \\
\hline & $\mathrm{Fe}$ & $\mathrm{Si}$ & $\mathrm{Cu}$ & $\mathrm{Mn}$ & $\mathrm{Zn}$ & $\overline{\mathrm{Mg}}$ & $\mathrm{Cr}$ & $\mathrm{Ti}$ & $\mathrm{Ni}$ & Al \\
\hline 1100 & $(1.0 \mathrm{Fe}$ & $+\mathrm{Si}$ & 0.20 & 0.05 & 0.10 & - & - & - & - & $99.00 * *$ \\
\hline 5154 & $(0.45 \mathrm{~F}$ & $(e+S i)$ & 0.10 & 0.10 & 0.20 & $\begin{array}{l}3.1- \\
3.9\end{array}$ & $\begin{array}{l}0.15- \\
0.35\end{array}$ & 0.20 & - & bal. \\
\hline 6061 & 0.7 & $\begin{array}{l}0.40- \\
0.80\end{array}$ & $\begin{array}{l}0.15- \\
0.40\end{array}$ & 0.15 & 0.25 & 0.15 & $\begin{array}{l}0.15- \\
0.35\end{array}$ & 0.15 & - & bal. \\
\hline $\mathrm{X} 8001$ & $\begin{array}{l}0.45- \\
0.70\end{array}$ & 0.17 & 0.15 & - & - & - & & - & $\begin{array}{l}0.9- \\
1.3\end{array}$ & bal. \\
\hline
\end{tabular}

*Maximum unless shown as range. **Minimum.

All specimens, except in one experiment where l/l6-in.-thick rolled sheet was used, were machined from 1/4-in. plate to the following dimensions: 1.400 by 1.385 by $0.200 \mathrm{in}$. After machining, the specimens were degreased and weighed. The surface roughness of the specimens was $32 \mu \mathrm{in}$. rms or less. Except for a few cases to be discussed separately, no further surface preparation was performed. The specimens were mounted in a titanium holder, and to eliminate any possibility of galvanic action between the aluminum and titanium, the sides of each specimen were wrapped with Teflon tape. The holders were fabricated in two halves and accommodated 10 specimens. The upper part of Fig. I shows a holder with the specimens in place and shows the location of the Teflon insulation. Practically no attack occurred under the Teflon, and in calculating corrosion rates from weight losses only the area of aluminum exposed to the flowing water was considered. In all cases this area was $12.5 \mathrm{~cm}^{2}$. The lower part of Fig. I shows a holder loaded with specimens and clamped together prior to insertion into a test loop. The channel dimensions were the same on both sides of the specimens. For most of the tests the channels had a venturi-type taper with minimum clearance between specimens and holder occurring in the axial center.

With the holder shown in Fig. 1, a velocity gradient existed over each specimen. Figure 2 shows how the velocity varied along the channel of the holder when fitted with 10 specimens and with a total of $30 \mathrm{gpm}$ flowing through the two channels of the holder. Because of the symmetry of the velocity over the first five and last five specimens, two different alloys were frequently tested in the same holder. Preliminary tests indicated that duplicate specimens exposed in the same velocity range either upstream or downstream from the center of the holder showed no significant difference in weight loss in a given test. 

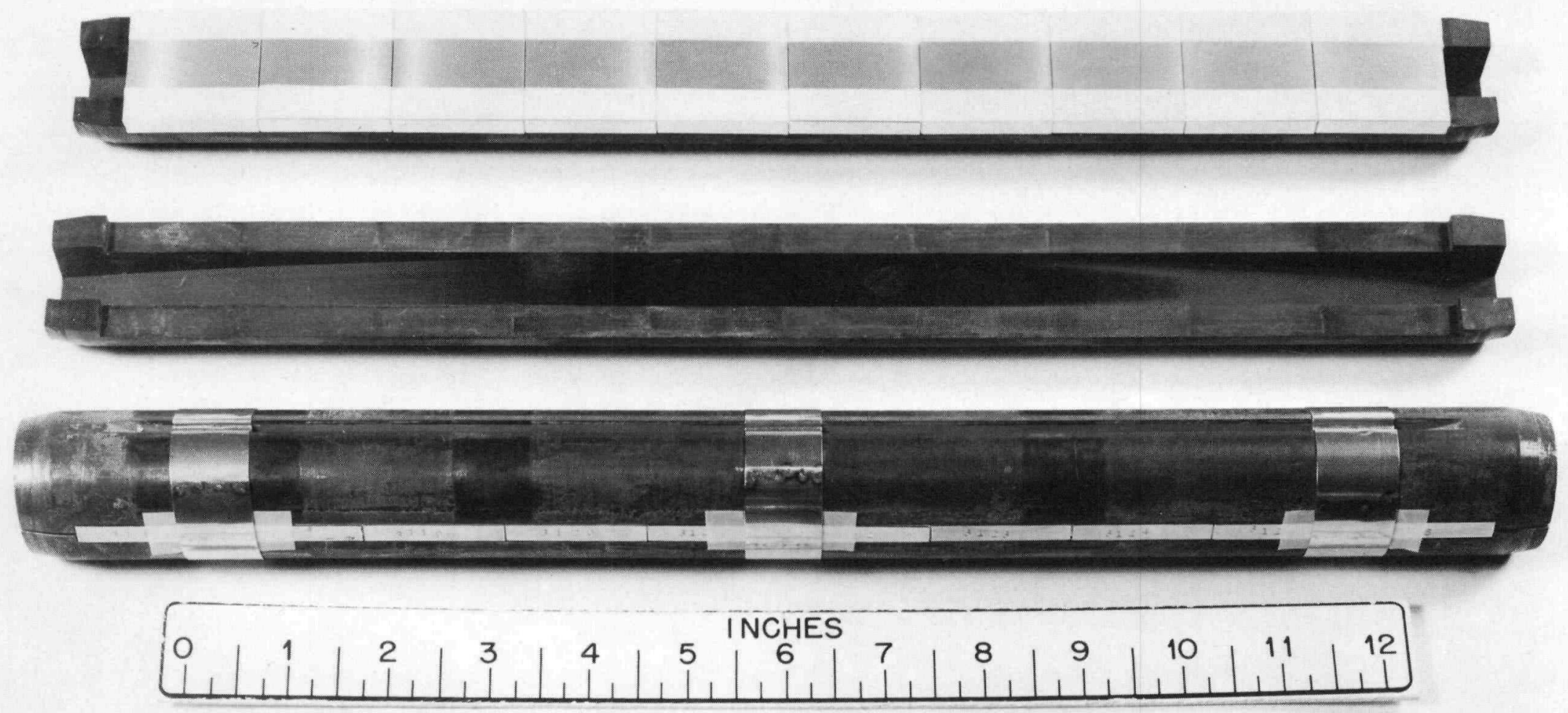

Fig. 1. Photograph of Specimen Holder and Test Specimens. 


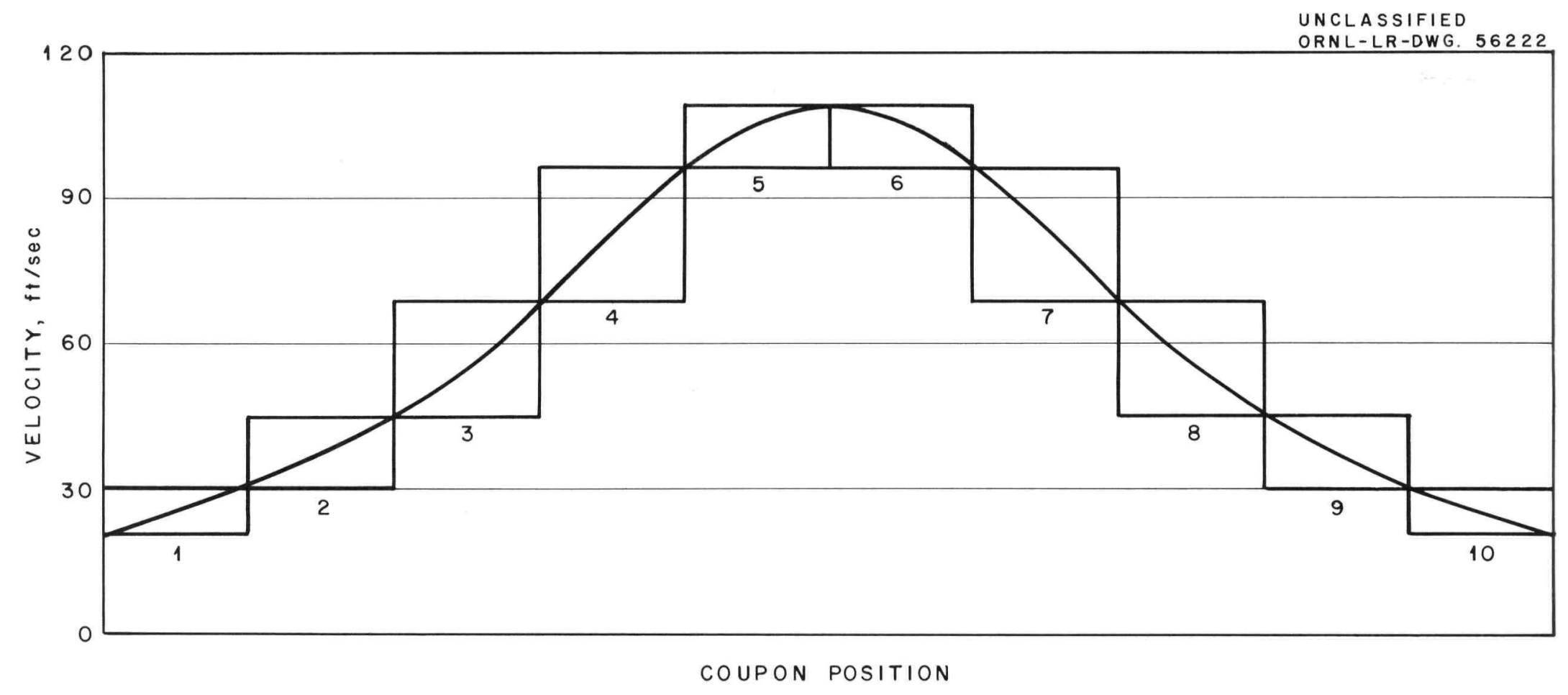

Fig. 2. The Velocity Gradient Over Specimens Exposed in a Venturi-Type Holder With a Flow Rate of $30 \mathrm{gpm}$. 
A few tests were run in a similar holder except that the flow channels were of constant dimensions; in this case all specimens were exposed at the same velocity. For the tests run in this type holder the specimens had the same dimensions as the other specimens except they were 1/16-in. thick.

Type 347 stainless steel loops equipped with 100-gpm pumps were used to circulate water past the specimens. This type of loop has been previously described, ${ }^{13}$ and no discussion of it will be made here other than to mention that the loops are capable of operation at high temperatures and pressures and that by use of bypass lines and suitable restrictor plates flow rates past the specimens can be varied over wide ranges. The specimens contained in assemblies as shown in Fig. 1 were exposed in the loop bypass lines.

Two different loops were used for the tests to be described. The loops were similar except for the geometry of the piping system and the manner in which the water quality was maintained. In one case the total loop volume was 22.5 liters, and the water quality was maintained by continuous feed and letdown of distilled water at a rate of 3 to 4 liters $/ \mathrm{hr}$. The average specific resistance of the water was 0.4 to $0.7 \times 10^{6} \mathrm{ohm}-\mathrm{cm}$; the ratio of aluminum surface area to water volume was $11 \mathrm{~cm}^{2} /$ liter. The second loop had a total volume of 22 liters and was operated with 17 liters of water (measured at room temperature). The quality of the water was maintained by continuously diverting a cooled side stream of water through a mixed-bed ion exchanger. The demineralization rate was about 3 liters/hr, and the average specific resistance of the water in the loop was 0.7 to $0.9 \times 10^{6} \mathrm{ohm}-\mathrm{cm}$. In this loop the ratio of aluminum surface area to water volume was approximately $12 \mathrm{~cm}^{2} /$ liter. Identical tests carried out in the two loops showed that there was no significant difference in results, and in the following section no differentiation between results obtained in the two loops is made. In all cases the water was thoroughly sparged with nitrogen before adding it to the loop to reduce the oxygen content to a very low value.

Since this testing program was conducted in support of the High-Flux Isotope Reactor, in which each fuel loading will last only about 10 days, most tests were of only 10-day duration. However, a few tests of both shorter and longer duration were conducted.

At the completion of a test the Teflon insulation was removed and the specimens were scrubbed with a soft brush, dried at $100^{\circ} \mathrm{C}$, and weighed. The oxide scale on all specimens was then removed by an a-c electrolysis in saturated boric acid solution followed by cathodic treatment in a chromic-phosphoric acid solution as recommended by Draley. ${ }^{4}$ The specimens were then reweighed. This procedure allowed a determination of the quantity of oxide on the specimen as well as the amount of metal actually corroded. In several cases the extent and nature of attack was such that the above procedure did not remove all of the corrosion product. When this occurred, the specimens had usually corroded so severely that it was pointless to attempt to determine the amount of metal corroded.

\section{RESULTS}

Effect of Temperature and Flow Rate. A number of loop runs was made in which 1100,6061 (T6 condition), X8001, and in a few cases, 5154 aluminum specimens were exposed to water at temperatures between 170 and $290^{\circ} \mathrm{C}$ for 10 -day periods. Table 2 shows the results obtained at $170^{\circ} \mathrm{C}$ where only one run was made.

It is apparent from Table 2 that there were no major differences among the three alloys under the conditions of test and that corrosion rates increased with increasing flow rate. All specimens showed random pitting ranging from 0.0005 to 
$0.002 \mathrm{in}$. in depth. There was no evidence of intergranular attack on any of the specimens.

Table 2. Average 10-Day Corrosion Rates of Aluminum Alloys in Flowing Water at $170^{\circ} \mathrm{C}$

\begin{tabular}{lrrr}
\hline \multirow{2}{*}{$\begin{array}{c}\text { Velocity } \\
(f p s)\end{array}$} & \multicolumn{3}{c}{ Corrosion Rate (mpy) } \\
\cline { 2 - 4 } & 1100 & 6061-T6 & X8001 \\
\hline $20-31$ & 33 & 28 & 38 \\
$31-44$ & 53 & 33 & 33 \\
$44-67$ & 68 & 61 & 52 \\
$67-95$ & 102 & 82 & 78 \\
$95-107$ & 125 & 120 & 100 \\
\hline
\end{tabular}

Two 10-day loop runs were made at $200^{\circ} \mathrm{C}$. Five specimens each of 1100 and 6061-T6 aluminum were exposed in each mun and in one run five specimens of 5154 were exposed. Ten X800I aluminum specimens were exposed in one run and five in the other. Except for the temperature, the conditions of these runs were identical to those of the first run. The average corrosion rates observed on all specimens during the 10-day tests are shown in Table 3.

Table 3. Average 10-Day Corrosion Rates of Aluminum Alloys in Flowing Water at $200^{\circ} \mathrm{C}$

\begin{tabular}{|c|c|c|c|c|}
\hline \multirow{2}{*}{$\begin{array}{l}\text { Velocity } \\
\text { Range } \\
\text { (fps) }\end{array}$} & \multicolumn{4}{|c|}{ Corrosion Rate (mpy) } \\
\hline & 1100 & $\underline{5154}$ & $6061-T 6$ & $\mathrm{X} 8001$ \\
\hline $\begin{array}{l}20-31 \\
31-44 \\
44-67 \\
67-95 \\
95-107\end{array}$ & $\begin{array}{rr}54, & 28 \\
41, & 33 \\
54, & 56 \\
98, & 117 \\
118, & 196\end{array}$ & $\begin{array}{r}32 \\
48 \\
71 \\
86 \\
100\end{array}$ & $\begin{array}{rr}27, & 57 \\
35, & 67 \\
62, & 72 \\
103, & 108 \\
127, & 130\end{array}$ & $\begin{array}{rrr}25, & 36, & 46 \\
68, & 56, & 49 \\
61, & 94, & 57 \\
95, & 110, & 117 \\
139, & 192, & 192\end{array}$ \\
\hline
\end{tabular}

As was the case at $170^{\circ} \mathrm{C}$, there appeared to be no significant difference among the alloys, and generally the higher the flow rate of water past the specimens the greater the corrosion rate. In all cases random pitting attack was observed, but clear-cut evidence of intergranular attack was not found. Figure 3 shows examples of the pits that were observed upon sectioning several of the specimens.

One loop run in which duplicate sets of 1100 and X8001 aluminum were exposed to water at $230^{\circ} \mathrm{C}$ for 10 days was made. The corrosion rates calculated from specimen weight losses are shown in Table 4 . 
UNCLASSIFIED

ORNL-LR-DWG. 56223

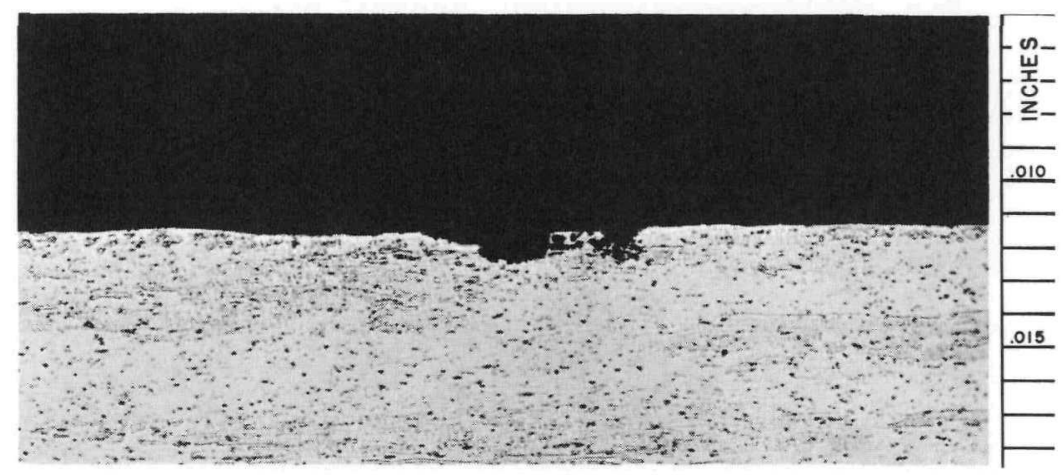

a. TYPE 1100 ALUMINUM, 95 TO $107 \mathrm{fps}(150 \mathrm{X})$.

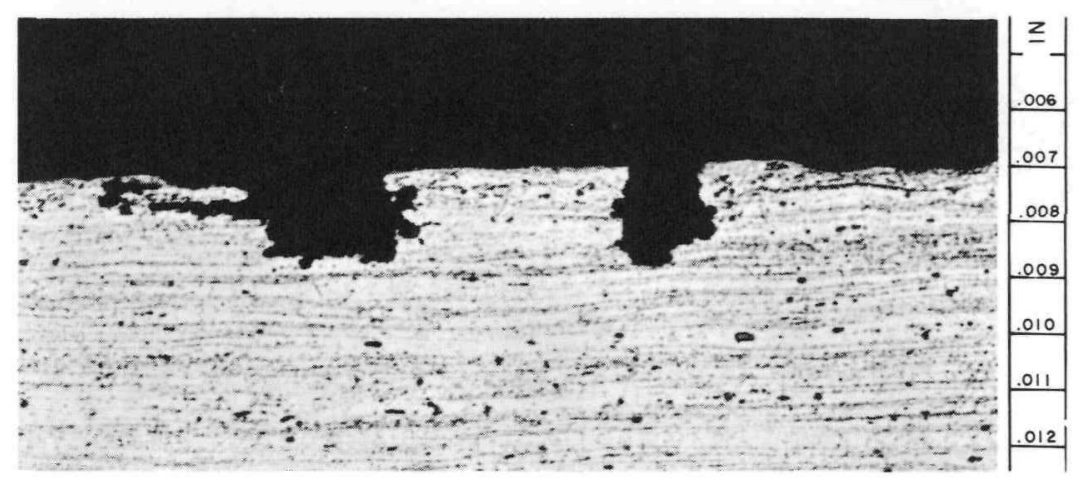

b. TYPE 5154 ALUMINUM, 20 TO $31 \mathrm{fps}(250 \mathrm{x})$.

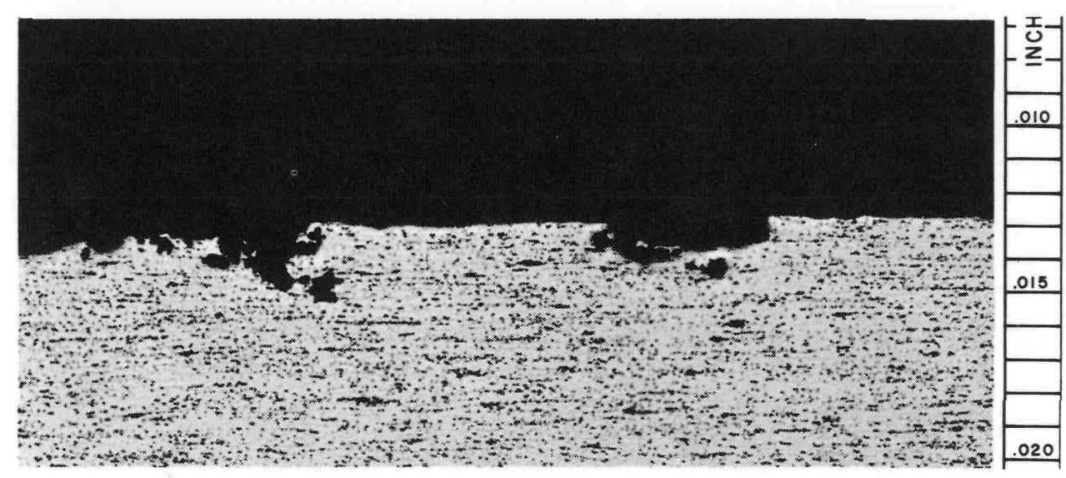

c. TYPE X8001 ALUMINUM, 20 TO 31 fps (150X).

Fig. 3. Pitting Attack on Aluminum Specimens Exposed for 10 Days in Flowing Distilled Water at $200^{\circ} \mathrm{C}$. Etched in $1 \% \mathrm{HF}$. 
Table 4. Average 10-Day Corrosion Rates of Types 1100 and X8001 Aluminum in Flowing Water at $230^{\circ} \mathrm{C}$

\begin{tabular}{|c|c|c|c|c|}
\hline \multirow{2}{*}{$\begin{array}{l}\text { Velocity } \\
\text { Range } \\
\text { (fps) }\end{array}$} & \multicolumn{4}{|c|}{ Corrosion Rate (mpy) } \\
\hline & \multicolumn{2}{|c|}{1100} & \multicolumn{2}{|c|}{$\mathrm{X} 8001$} \\
\hline $\begin{array}{l}20-31 \\
31-44 \\
44-67 \\
67-95 \\
95-107\end{array}$ & $\begin{array}{r}35 \\
62 \\
78 \\
106 \\
210\end{array}$ & $\begin{array}{r}66 \\
67 \\
86 \\
132 \\
229\end{array}$ & $\begin{array}{r}57 \\
55 \\
74 \\
149 \\
272\end{array}$ & $\begin{array}{r}27 \\
49 \\
56 \\
126 \\
252\end{array}$ \\
\hline
\end{tabular}

Comparison of Table 4 with Tables 2 and 3 shows that relatively little difference in behavior was observed with 1100 and X8001 over the temperature range of 170 to $230^{\circ} \mathrm{C}$. As with all other specimens, occasional pitting to a maximum depth of about 0.002 in. was observed, but no evidence of intergranular or subsurface attack was found. All specimens exposed at temperatures up to and including $230^{\circ} \mathrm{C}$ were descaled satisfactorily.

A relatively large number of runs was made at $260^{\circ} \mathrm{C}$ with types 1100,6061 , and X8001 aluminum specimens, and in one mun type 5154 specimens were exposed. With 1100 aluminum the descaling procedure employed was not completely satisfactory, and complete removal of oxide from the specimens was not always obtained. Figure 4 shows typical examples of the corroded surface of the 1100 aluminum at the highest and lowest flow rates. The apparent voids in the metal were filled with corrosion products which could not be removed by the descaling procedure. At the highest flow rates fewer voids were present than at the lower flow rates and reasonably good values were probably obtained for the corrosion rate. In some runs at $260^{\circ} \mathrm{C}$ relatively few voids were apparent and in other runs many voids were visible upon sectioning the test specimen. Thus the results showed. large variations.

Type 5154 aluminum specimens were so extensively corroded at $260^{\circ} \mathrm{C}$ that descaling was pointless.

Specimens of 6061 aluminum exposed to water at $260^{\circ} \mathrm{C}$ showed much void formation in some runs and essentially none in other mus. Figure 5 shows two extreme cases. Because of the inconsistent behavior, reproducibility of results from run to run was poor.

Figure 6 shows similar photomicrographs of X8001 specimens exposed at $260^{\circ} \mathrm{C}$. There was some surface irregularity on a few of the specimens exposed at low velocities, but the complete absence of the type of attack seen in Figs. $4 \mathrm{a}$ and 5b is apparent. Descaling of these specimens was essentially complete.

Table 5 shows the average corrosion rates observed with 1100 aluminum at $260^{\circ} \mathrm{C}$, and Table 6 shows the same data for 6061 aluminum. Corrosion rates for those specimens which suffered severe localized attack and could not be descaled are not shown. The corrosion rates included in the tables were obtained from specimens which appeared to be completely descaled, but probably the corrosion scale was not entirely removed in all cases. 
UNCLASSIFIED

ORNL-LR-DW G. 56224

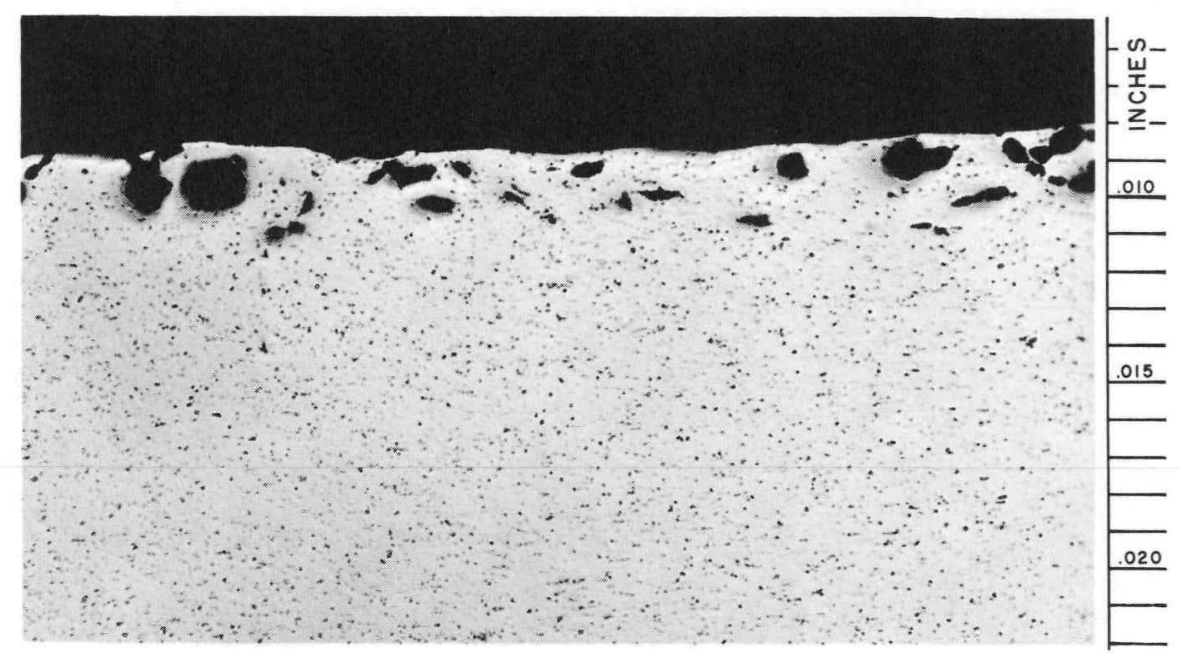

a. VELOCITY GRADIENT, 20 TO $31 \mathrm{fps}$. As POLISHED (150X)

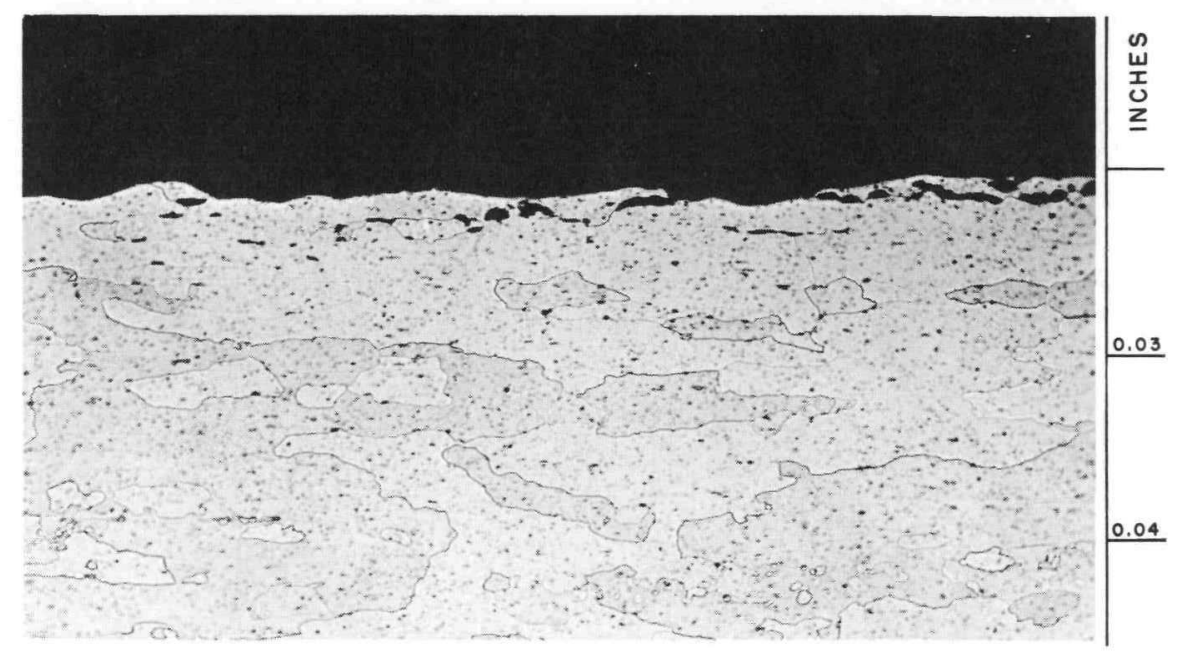

b. VELOCITY GRADIENT, 95 TO 107 fps. ETCHED IN $1 \%$ HF $(75 X)$.

Fig. 4. Surface Condition of Type 1100 Aluminum Specimens Exposed for 10 Days at $260^{\circ} \mathrm{C}$ in Distilled Water at Low and High Flow Rates. 
UNCLASSIFIED

ORNL-LR-DWG. 56225

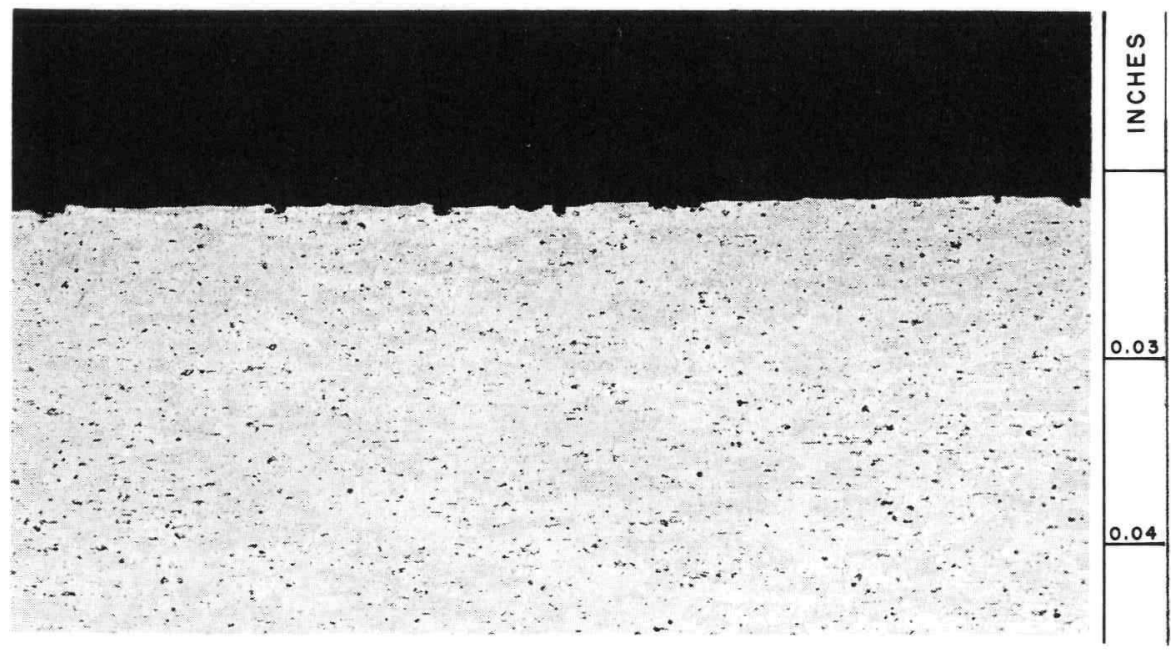

a. VELOCITY GRADIENT, 20 TO $31 \mathrm{fps}(75 \mathrm{X})$

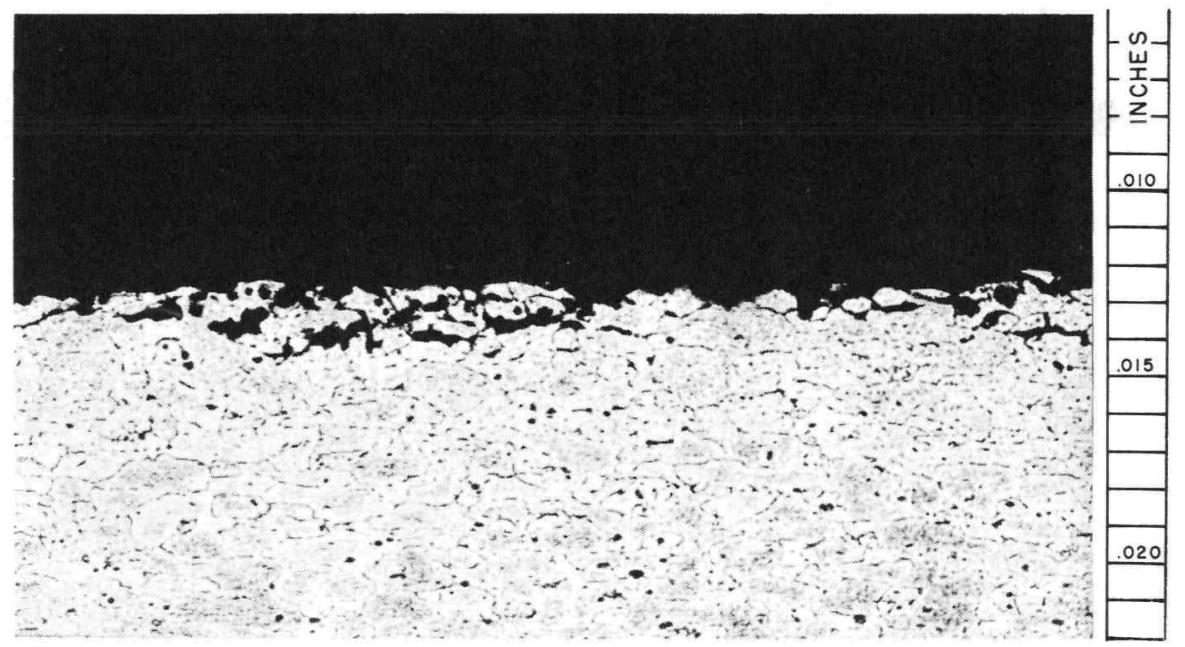

b. VELOCITY GRADIENT, 20 TO $31 \mathrm{fps}(150 \mathrm{X})$

Fig. 5. Different Types of Attack Experienced by Type 6061 Aluminum Specimens Exposed for 10 Days at $260^{\circ} \mathrm{C}$ in Flowing Distilled Water. Etched in $1 \% \mathrm{HF}$. 


\author{
UNCLASSIFIED \\ ORNL-LR-DWG. 56226
}

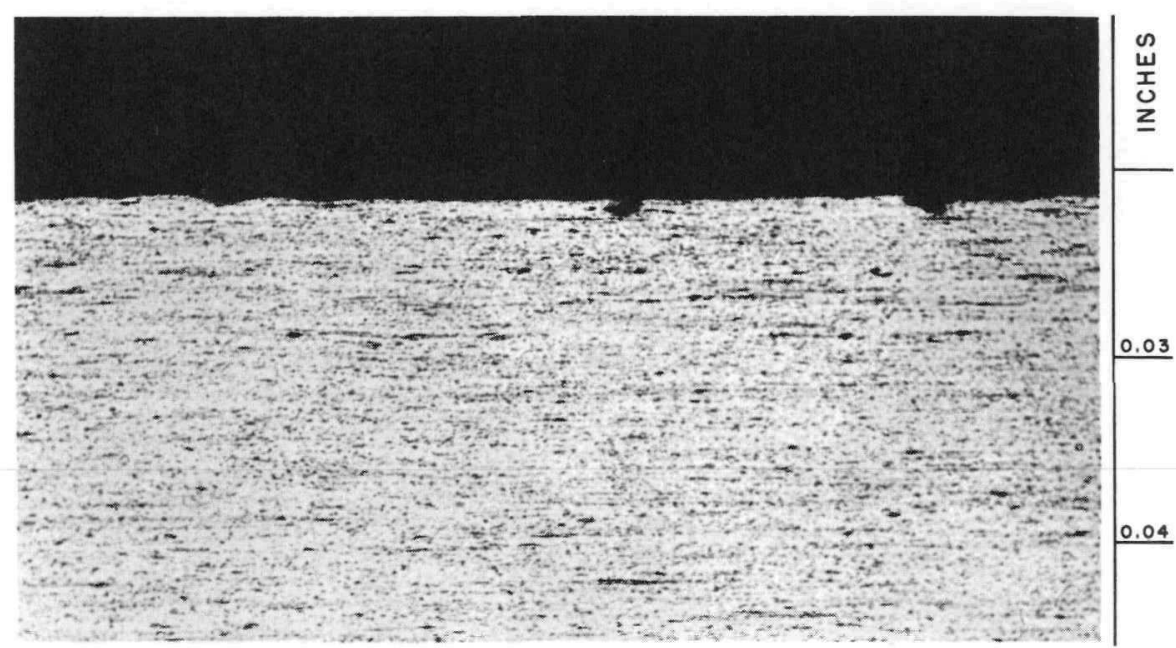

a. VELOCITY GRADIENT, 20 TO $31 \mathrm{fps}$

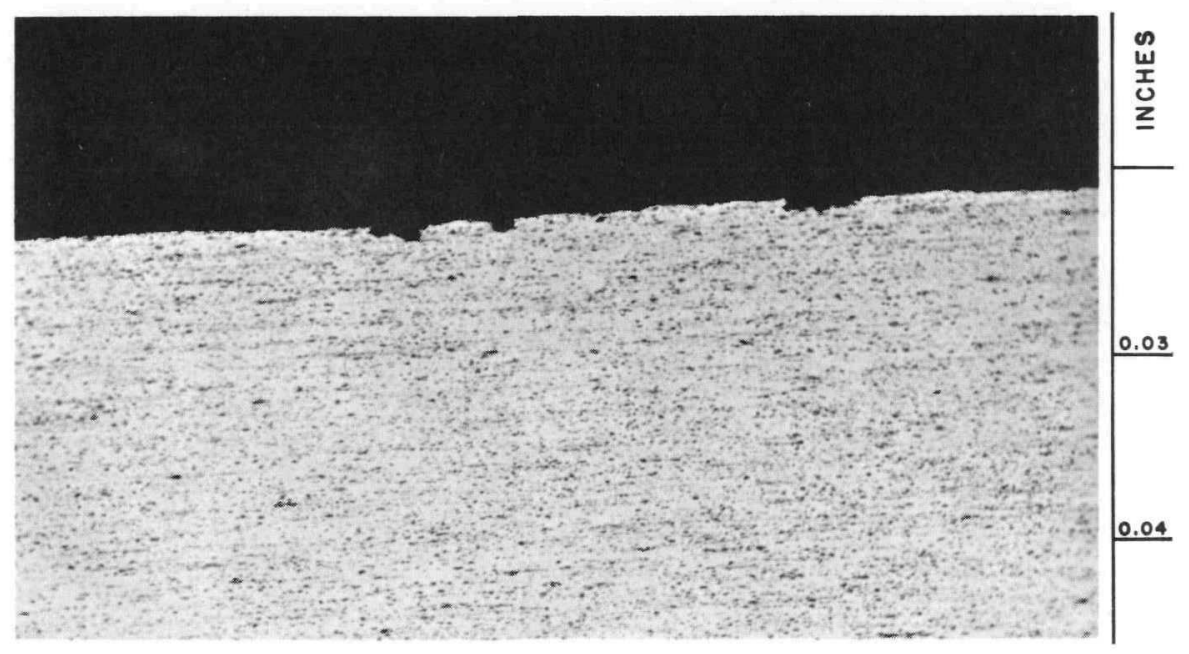

b. VELOCITY GRADIENT, 95 TO $107 \mathrm{fps}$

Fig. 6. Typical Surface Attack Experienced by Type X8001 Aluminum Specimens Exposed for 10 Days at $260^{\circ} \mathrm{C}$ in Flowing Distilled Water. Etched in 1\% HF. Magnification $75 X$. 
Table 5. Average 10-Day Corrosion Rates of 1100 Aluminum Specimens in Flowing Water at $260^{\circ} \mathrm{C}$

\begin{tabular}{lrrrrr}
\hline $\begin{array}{l}\text { Velocity } \\
\text { Range } \\
(f p s)\end{array}$ & \multicolumn{5}{c}{$\begin{array}{c}\text { Corrosion Rate } \\
\text { (mpy) }\end{array}$} \\
\hline $20-31$ & 77 & 85 & 92 & $*$ & $*$ \\
$31-44$ & 31 & 32 & 19 & $*$ & $*$ \\
$44-67$ & 30 & 14 & 54 & $*$ & $*$ \\
$67-95$ & 96 & 147 & 93 & 133 & 93 \\
$95-105$ & 199 & 269 & 311 & 228 & 227 \\
\hline
\end{tabular}

*Descaling incomplete.

Table 6. Average 10-Day Corrosion Rates of 6061 Aluminum Specimens in Flowing Water at $260^{\circ} \mathrm{C}$

\begin{tabular}{lrrrrr}
\hline $\begin{array}{l}\text { Velocity } \\
\text { Range } \\
(f p s)\end{array}$ & \multicolumn{5}{c}{$\begin{array}{c}\text { Corrosion Rate } \\
\text { (mpy) }\end{array}$} \\
\hline & & \multicolumn{5}{c}{} \\
$20-31$ & 34 & 43 & 28 & 76 & $*$ \\
$31-44$ & 42 & 29 & 29 & 90 & 31 \\
$44-67$ & 47 & - & 50 & 100 & 82 \\
$67-95$ & 85 & 103 & 116 & 142 & $*$ \\
$95-105$ & 190 & 215 & 267 & 294 & $*$ \\
\hline
\end{tabular}

*Descaling incomplete.

Table 7 shows the corrosion rates of $\mathrm{X} 8001$ aluminum specimens exposed at $260^{\circ} \mathrm{C}$. The average corrosion rates and the standard deviations are also shown. Although the reproducibility of the data is not as good as one would like, it appears that the corrosion rate of $\mathrm{X} 8001$ aluminum was essentially independent of flow rate in the range of 20 to $67 \mathrm{fps}$. At higher flow rates the extent of corrosion increased. As in all tests at lower temperatures, some random pitting varying in depth between 0.0005 and 0.002 in. was observed.

Only one loop run was made at $290^{\circ} \mathrm{C}$, and at this temperature 1100 and 6061 specimens showed very large weight gains that resulted from severe corrosion of the alloys. Figure 7 shows the severity of attack on 1100 aluminum, and Fig. 8 shows that on 6061 aluminum. On the other hand, the X8001 alloy corroded at rates somewhat less than at $260^{\circ} \mathrm{C}$, and no significant localized attack occurred. Figure 9 shows photomicrographs of transverse sections of two specimens showing the uniform nature of the attack. The corrosion rates observed on the X800I specimens are given in Table 8. 


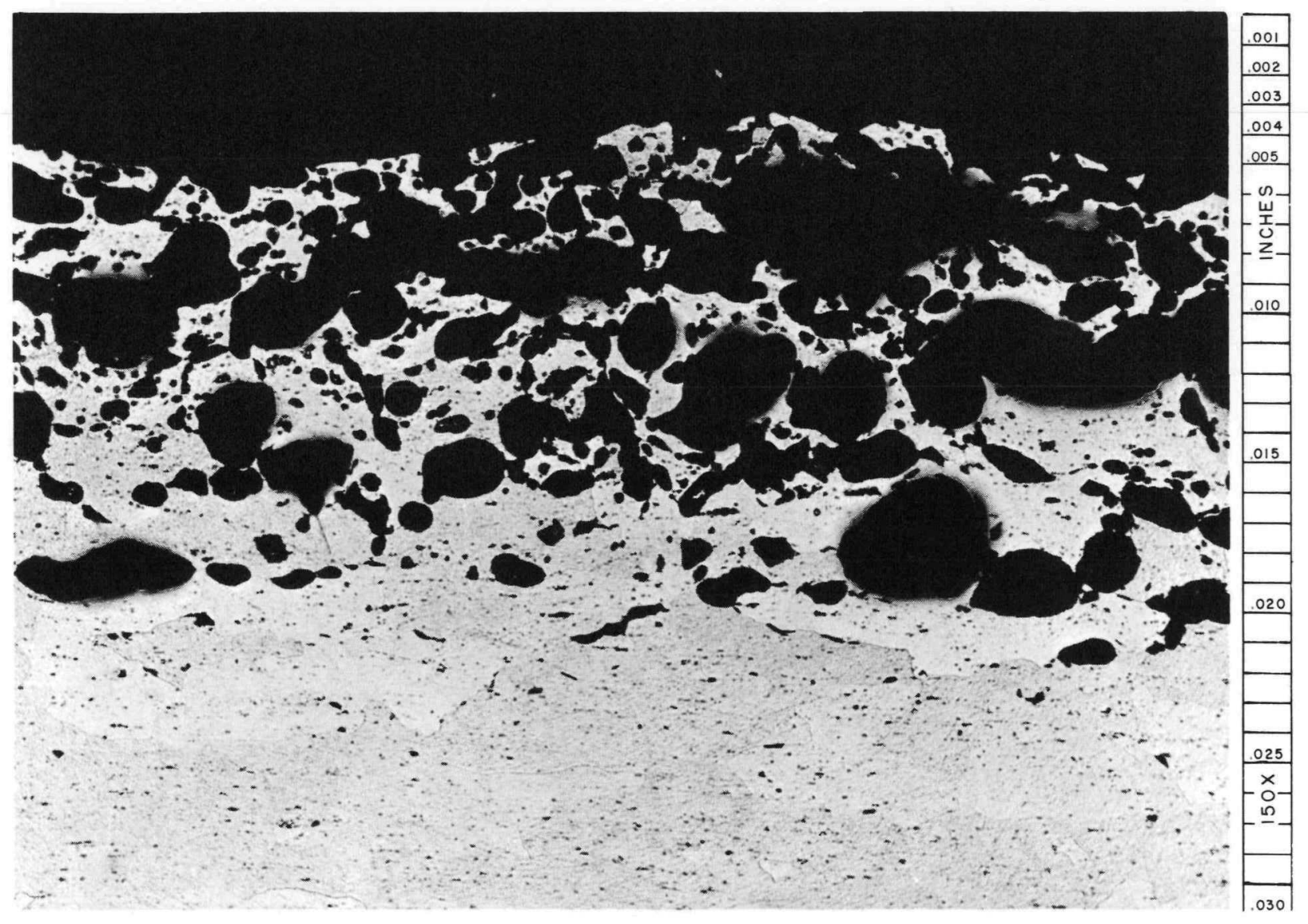

Fig. 7. Condition of Type 1100 Aluminum After 10 Days at $290^{\circ} \mathrm{C}$ in Distilled Water at a Flow Rate of 20 to $31 \mathrm{fps}$. Etched in $1 \%$ HF. Magnification $150 \mathrm{X}$. 
UNCLASSIFIED

ORNL-LR - DW G.

56228

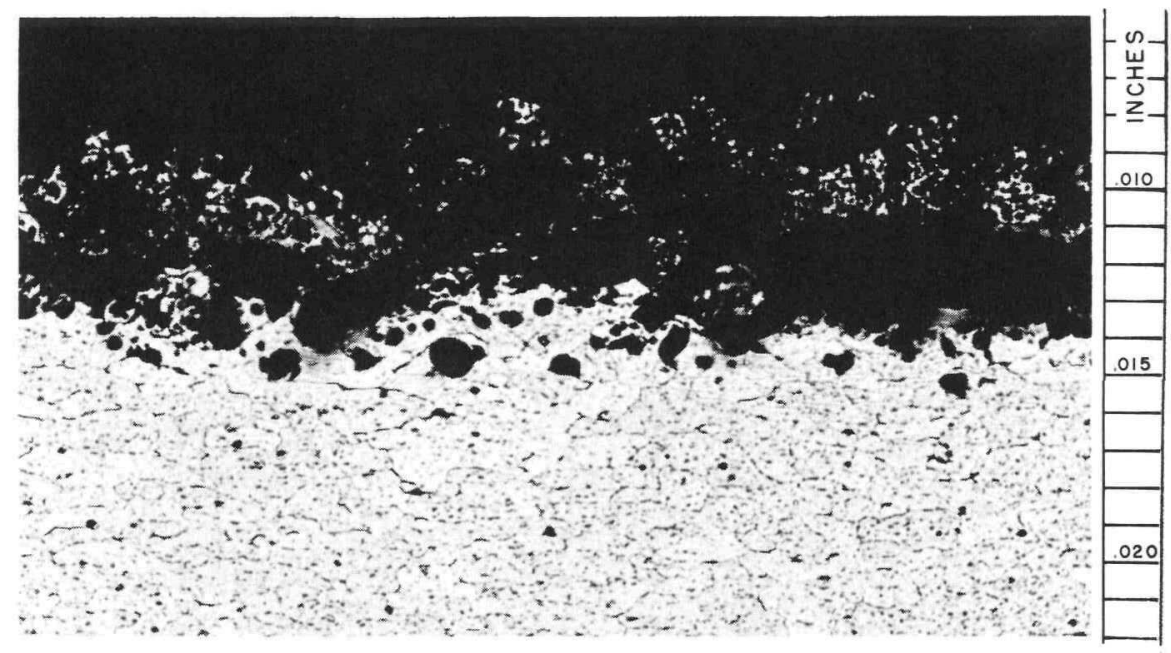

a. VELOCITY GRADIENT, 20 TO $31 \mathrm{fps}$

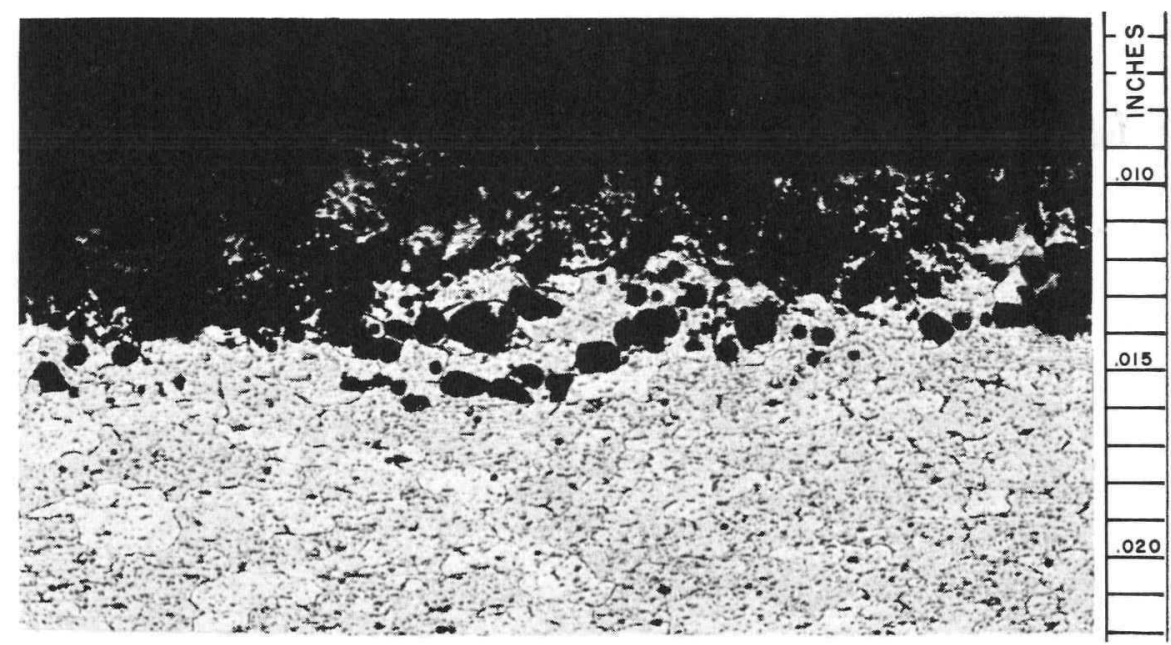

b. VELOCITY GRADIENT, 95 TO $107 \mathrm{fps}$

Fig. 8. Condition of Type 6061 Aluminum Specimens After 10 Days at $290^{\circ} \mathrm{C}$ in Flowing Distilled Water. Etched in $1 \% \mathrm{HF}$. Magnification $150 \mathrm{X}$. 
UNCLASSIFIED

ORNL-LR-DW G.
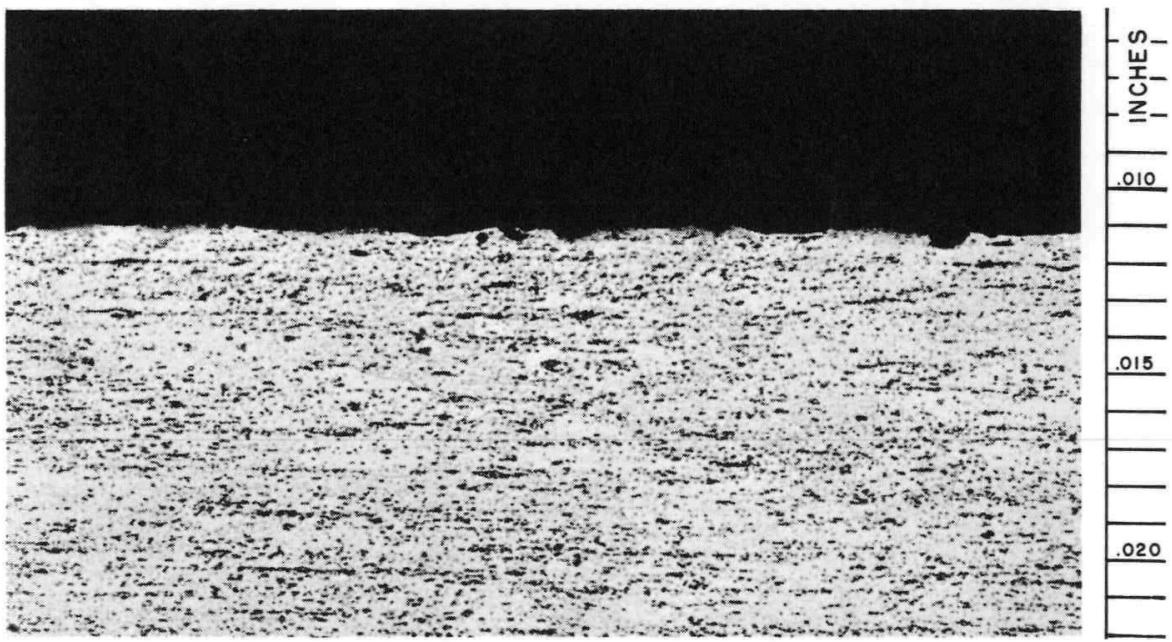

a. VELOCITY GRADIENT, 20 TO $31 \mathrm{fps}$

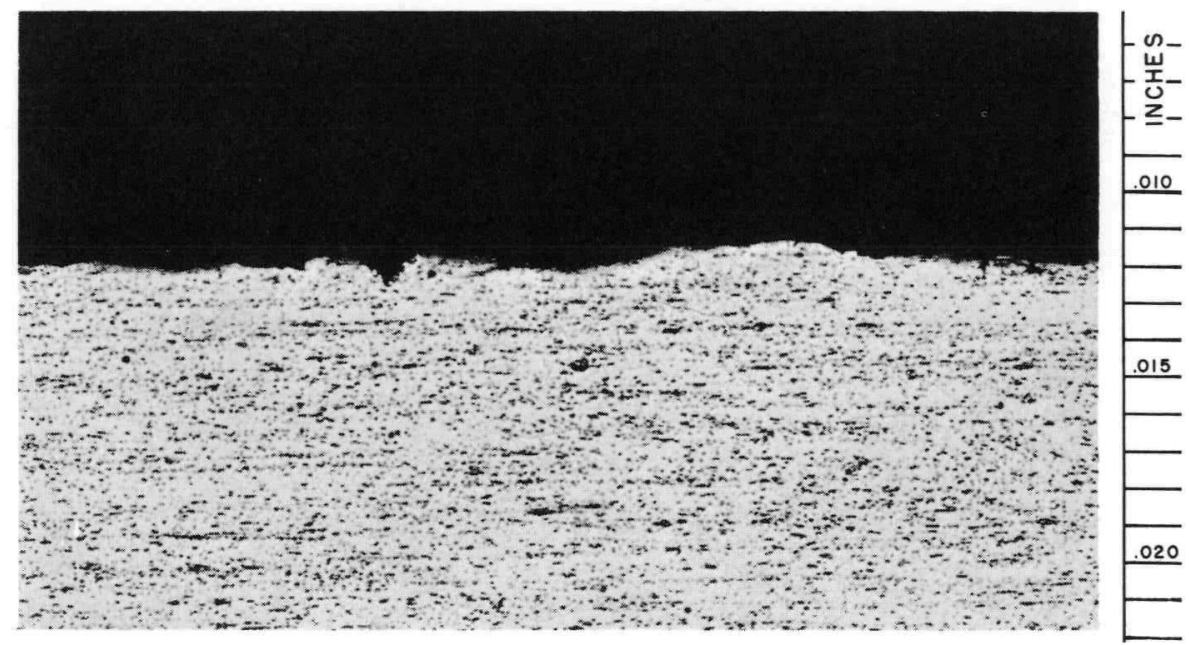

b. VELOCITY GRADIENT, 90 TO 107 fps

Fig. 9. Condition of Type $\times 8001$ Aluminum Specimens After 10 Days at $290^{\circ} \mathrm{C}$ in Flowing Distilled Water. Etched in $1 \% \mathrm{HF}$. Magnification $150 \mathrm{X}$. 
Table 7. Average 10-Day Corrosion Rates of X8001 Aluminum Specimens in Flowing Water at $260^{\circ} \mathrm{C}$

\begin{tabular}{|c|c|c|c|c|c|c|c|c|}
\hline $\begin{array}{l}\begin{array}{l}\text { Velocity } \\
\text { Range } \\
\text { (fps) }\end{array} \\
20-31\end{array}$ & \multicolumn{6}{|c|}{ Corrosion Rate (mpy) } & \multirow{2}{*}{$\begin{array}{c}\text { Average } \\
\begin{array}{c}\text { Corrosion Rate } \\
\text { (mpy) }\end{array} \\
61 \\
53 \\
69 \\
149 \\
328\end{array}$} & $\begin{array}{c}\begin{array}{c}\text { Standard } \\
\text { Deviation } \\
(\%)\end{array} \\
33\end{array}$ \\
\hline $\begin{array}{l}20-31 \\
31-44 \\
44-67 \\
67-95 \\
95-107\end{array}$ & $\begin{array}{r}76 \\
79 \\
73 \\
159 \\
284\end{array}$ & $\begin{array}{r}39 \\
48 \\
63 \\
116 \\
268\end{array}$ & $\begin{array}{r}45 \\
44 \\
54 \\
159 \\
338\end{array}$ & $\begin{array}{r}86 \\
37 \\
51 \\
151 \\
395\end{array}$ & $\begin{array}{r}- \\
53 \\
70 \\
141 \\
361\end{array}$ & $\begin{array}{r}57 \\
56 \\
105 \\
166 \\
322\end{array}$ & & $\begin{array}{l}33 \\
27 \\
28 \\
12 \\
14\end{array}$ \\
\hline
\end{tabular}

Table 8. Corrosion of X8001 Aluminum in Flowing Water at $290^{\circ} \mathrm{C}$ During a 10 -Day Test

\begin{tabular}{lccccc}
\hline Flow rate (fps) & $20-31$ & $31-44$ & $44-67$ & $67-95$ & $95-107$ \\
Corrosion rate (mpy) & 61 & 57 & 53 & 96 & 206 \\
\hline
\end{tabular}

In summary, the above series of tests showed that during 10-day tests $x 8001$ aluminum specimens suffered no localized attack except for a few relatively shallow pits at temperatures as high as $290^{\circ} \mathrm{C}$, whereas 1100,5154 , and 6061 aluminum alloys suffered severe intergranular or subsurface attack at $260^{\circ} \mathrm{C}$ and above. At $230^{\circ} \mathrm{C}$ and below, all four alloys showed comparable corrosion behavior. At all temperatures investigated, the alloys generally corroded at a faster rate the higher the flow rate of the water. However, at 260 and $290^{\circ} \mathrm{C}$ little, if any, effect of flow rate in the range of 20 to $67 \mathrm{fps}$ was observed with X8001 aluminum specimens.

Corrosion-Product Retention. Since corrosion products on the surface of the aluminum fuel-element cladding interfere with the transfer of heat, it was of interest to examine how much of the corrosion product was retained by the specimens at different flow rates and temperatures. One method of expressing the relationship between the metal corroded and the corrosion products adhering to the aluminum is the ratio of the weight of corrosion product per unit area to the weight of metal corroded. Complete retention of the corrosion product would be indicated by a ratio of 2.22 , assuming the corrosion product to be pure aluminum oxide monohydrate. The results obtained by examining the data in this manner are shown in Table 9. At any given temperature and flow rate the ratio appeared to be independent of alloy type and at 170,200 , and $230^{\circ} \mathrm{C}$, the average of the ratios of all alloys and the standard deviation are shown. Because of the difficulty of descaling all alloys except X8001 at temperatures of 260 and $290^{\circ} \mathrm{C}$, only the data obtained with $\mathrm{X} 8001$ specimens are included at those temperatures.

It should be noted in Table 9 that at all temperatures the ratios decreased as the flow rate increased and that in a given velocity range similar values of the ratio were obtained at all temperatures. It should be remembered that at any temperature the quantity of metal corroded increased with velocity (see Tables 2 through 8 ) so that the decrease in ratio with increasing velocity was greater than the actual decrease in oxide thickness with velocity. 
Table 9. The Ratio of the Weight of Corrosion Products to the Weight of Metal Corroded at Various

Temperatures and Flow Rates

\begin{tabular}{|c|c|c|c|c|c|}
\hline $\begin{array}{l}\text { Velocity } \\
\text { Range } \\
\text { (fps) }\end{array}$ & $170^{\circ} \mathrm{C}$ & $\begin{array}{l}\text { Weight of } \\
\text { Weight of } \\
200^{\circ} \mathrm{C}\end{array}$ & $\begin{array}{c}\text { Corrosion Products } \\
\text { Aluminum Corroded } \\
230^{\circ} \mathrm{C}\end{array}$ & $260^{\circ} \mathrm{C}$ & $290^{\circ} \mathrm{C}$ \\
\hline $\begin{array}{l}20-31 \\
31-44 \\
44-67 \\
67-95 \\
95-107\end{array}$ & $\begin{array}{l}1.19 \pm 0.10 \\
1.14 \mp 0.16 \\
0.99 \mp 0.20 \\
0.74 \mp 0.13 \\
0.49 \pm 0.13\end{array}$ & $\begin{array}{l}1.28+0.10 \\
1.24 \mp 0.16 \\
1.06 \mp 0.06 \\
0.77 \mp 0.05 \\
0.40 \pm 0.01\end{array}$ & $\begin{array}{l}1.44 \pm 0.33 \\
1.35 \mp 0.38 \\
0.76 \pm 0.27 \\
0.32 \mp 0.05 \\
0.15 \pm 0.05\end{array}$ & $\begin{array}{l}1.53 \pm 0.37 \\
1.62 \mp 0.28 \\
1.36 \mp 0.31 \\
0.57 \mp 0.16 \\
0.20 \pm 0.04\end{array}$ & $\begin{array}{l}1.45 \\
1.56 \\
1.63 \\
0.82 \\
0.30\end{array}$ \\
\hline
\end{tabular}

Examination of the corrosion products formed at all temperatures by $\mathrm{x}$-ray diffraction showed only boehmite, $\alpha_{A_{2}} \mathrm{O}_{3} \cdot \mathrm{H}_{2} \mathrm{O}$, to be present as has been observed by other investigators. ${ }^{14}$ However, water in varying amounts is usually entrapped in the boehmite, and small concentrations of impurities are always present. Since chemical analyses of the corrosion-product films were not obtained, the actual amount of aluminum in the film is not known. As mentioned above, the ratio of the weight of corrosion products to the weight of metal corroded would be 2.22 if one assumed that the corrosion product were boehmite, all of which remained on the surface of origin. If the corrosion product contained water and other impurities, as it surely must, this ratio would be even greater. Thus from Table 9 it is seen that at low flow no more than about $70 \%$ of the corrosion product was retained on the surface of the aluminum, and at high flow rates $7 \%$ or less remained on the specimens.

Effect of Time. Several loop runs of different duration were carried out to determine the effect of time on the corrosion of 1100 and X8001 aluminum alloys by water at $260^{\circ} \mathrm{C}$. Duplicate specimens were exposed in each of the five velocity ranges. Specimens were weighed before exposure and after descaling at the conclusion of each run, and the extent of corrosion was determined from the weight losses. Tests of 13, 25, 48 (duplicate experiments), 123, 204, 300, 360, 478, and $504 \mathrm{hr}$ duration were conducted. New specimens were used in each run.

(1) 1100 Aluminum. A light-gray, uniform film covered most exposed areas of the specimens tested at velocities up to $67 \mathrm{fps}$ for periods of $123 \mathrm{hr}$ or less. At higher velocities in the tests of $123 \mathrm{hr}$ or less, the aluminum surfaces exposed to the flowing water appeared to be nearly free of corrosion product except for a few isolated areas which were covered with a light-gray scale. In most cases the descaling treatment appeared to remove the corrosion product. In those few cases where the corrosion product was not completely removed, as evidenced by the fact that the specimens showed slight weight gains even after defilming, microscopic examination failed to show serious attack. Table 10 shows the weight losses observed on those specimens exposed for periods of $123 \mathrm{hr}$ or less and the calculated corrosion rates.

In tests that lasted for more than $123 \mathrm{hr}$ all specimens as removed from the loop were covered with very heavy, grayish films. Attempts to descale these specimens were unsuccessful, apparently because of the nature of the attack (see Fig. 4). Thus it was not possible to obtain meaningful corrosion rates for 1100 aluminum specimens exposed for times greater than $123 \mathrm{hr}$. In all cases corrosion damage was extensive. 
Table 10. Effect of Time on the Corrosion of 1100 Aluminum Specimens by

Flowing Water at $260^{\circ} \mathrm{C}$

\begin{tabular}{|c|c|c|c|}
\hline $\begin{array}{l}\text { Time } \\
(h r)\end{array}$ & $\begin{array}{l}\text { Velocity } \\
\text { Range } \\
\text { (fps) }\end{array}$ & $\begin{array}{c}\text { Weight } \\
\text { Loss } \\
\left(\mathrm{mg} / \mathrm{cm}^{2}\right)\end{array}$ & $\begin{array}{c}\text { Corrosion } \\
\text { Rate } \\
\text { (mpy) }\end{array}$ \\
\hline 13 & $\begin{array}{l}20-31 \\
31-44 \\
44-67 \\
67-95 \\
95-107\end{array}$ & $\begin{array}{ll}1.1, & 0.8 \\
1.1, & 0.9 \\
2.4, & 1.9 \\
2.7, & 3.0 \\
2.9, & 3.4\end{array}$ & $\begin{array}{lr}117, & 80 \\
117, & 95 \\
252, & 204 \\
284, & 314 \\
307, & 358\end{array}$ \\
\hline 25 & $\begin{array}{l}20-31 \\
31-44 \\
44-67 \\
67-95 \\
95-107\end{array}$ & $\begin{array}{ll}3.9, & 3.5 \\
4.0, & 4.3 \\
4.0, & 5.3 \\
5.2, & 5.0 \\
6.1, & 5.7\end{array}$ & $\begin{array}{ll}205, & 185 \\
211, & 228 \\
211, & 280 \\
278, & 267 \\
325, & 303\end{array}$ \\
\hline 48 & $\begin{array}{l}20-31 \\
31-44 \\
44-67 \\
67-95 \\
95-107\end{array}$ & $\begin{array}{ll}1.2, & 3.5 \\
4.0, & 1.6 \\
4.8, & 1.9 \\
4.7, & 6.6 \\
10.6, & 7.3\end{array}$ & $\begin{array}{rr}31, & 93 \\
106, & 43 \\
128, & 49 \\
123, & 174 \\
193, & 281\end{array}$ \\
\hline 48 & $\begin{array}{l}20-31 \\
31-44 \\
44-67 \\
67-95 \\
95-107\end{array}$ & $\begin{array}{c}*, * \\
*, * \\
0.6, * \\
4.9,1.7 \\
6.9,11.1\end{array}$ & $\begin{array}{c}-,- \\
-,- \\
15,- \\
129, \quad 46 \\
184,296\end{array}$ \\
\hline 123 & $\begin{array}{l}20-31 \\
31-44 \\
44-67 \\
67-95 \\
95-107\end{array}$ & $\begin{array}{rr}3.5, & * \\
* & 5.4 \\
1.0, & 6.1 \\
11.3, & 12.2 \\
30.2, & 28.0\end{array}$ & $\begin{array}{rr}37, & - \\
-, & 57 \\
11, & 65 \\
120, & 129 \\
320, & 297\end{array}$ \\
\hline
\end{tabular}

*Slight weight gains observed after defilming.

(2) $\mathrm{X} 8001$ Aluminum. In all tests the appearance of the $\mathrm{X} 8001$ aluminum specimens was characterized by a light-gray film distributed uniformly over the exposed. surfaces. The defilming treatment successfully removed the corrosion product from the specimens. Table 11 shows the weight losses observed and the calculated corrosion rates. Figures 10 and 11 show the weight losses of the duplicate specimens plotted against exposure time. As shown in Fig. 10, the observed weight losses at the three lowest-velocity ranges increased with time for about $200 \mathrm{hr}$, after which only slight linear increases were observed. Although the data scatter considerably, the slopes of the linear portion of each curve as drawn correspond to corrosion rates of 5,10 , and $15 \mathrm{mpy}$ in the velocity ranges of 20 to $30 \mathrm{fps}$, 31 to $44 \mathrm{fps}$, and 44 to $67 \mathrm{fps}$, respectively. In the two higher-velocity ranges, weight losses increased at an appreciable rate with increased exposure time, as shown in Fig. 1l. Slopes of the linear portion of these curves indicate corrosion rates of 60 mpy in the range of 67 to 95 fps and $220 \mathrm{mpy}$ for specimens exposed at 95 to $107 \mathrm{fps}$. 

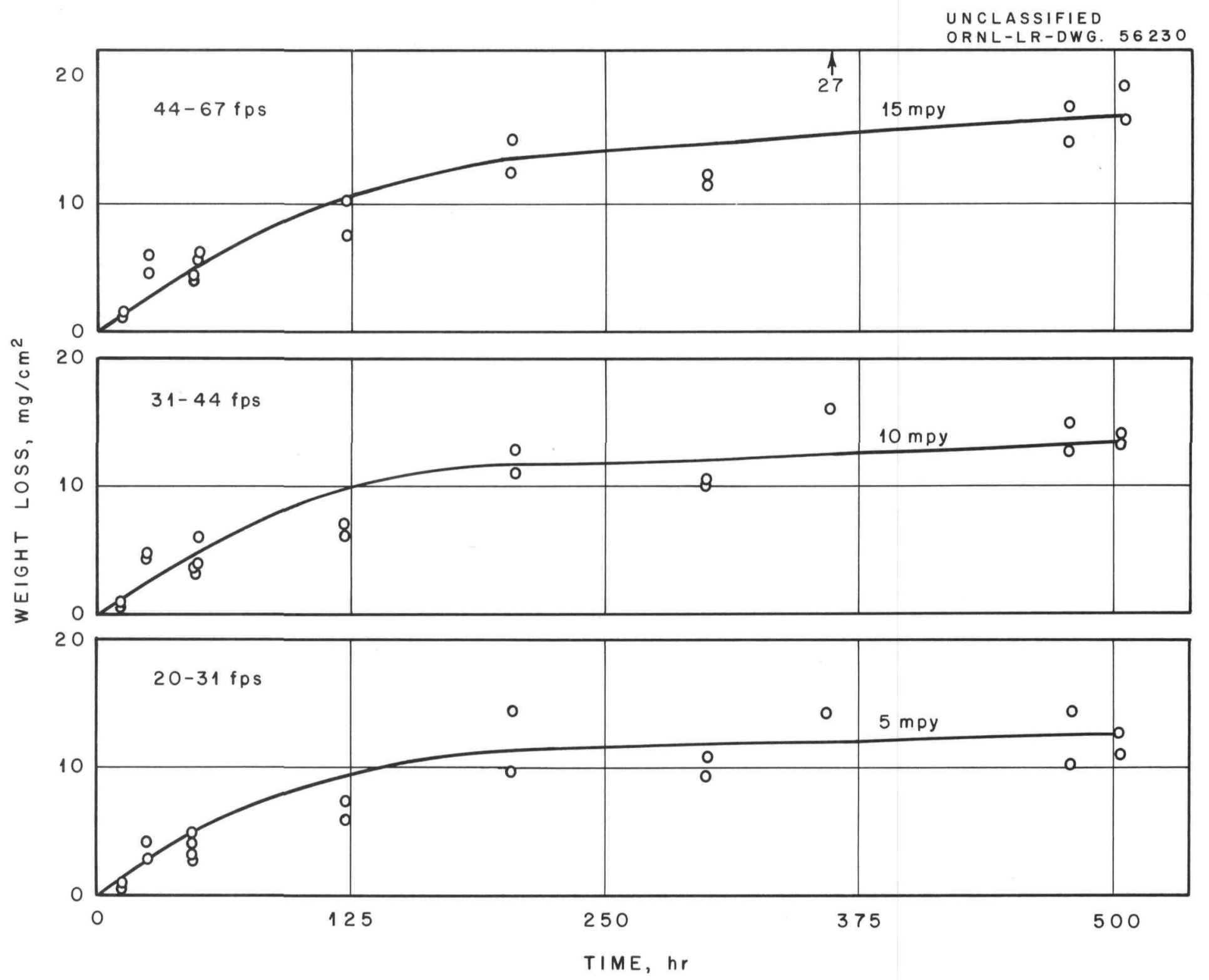

Fig. 10. The Corrosion of Type $\times 8001$ Aluminum in Water at $260^{\circ} \mathrm{C}$. 


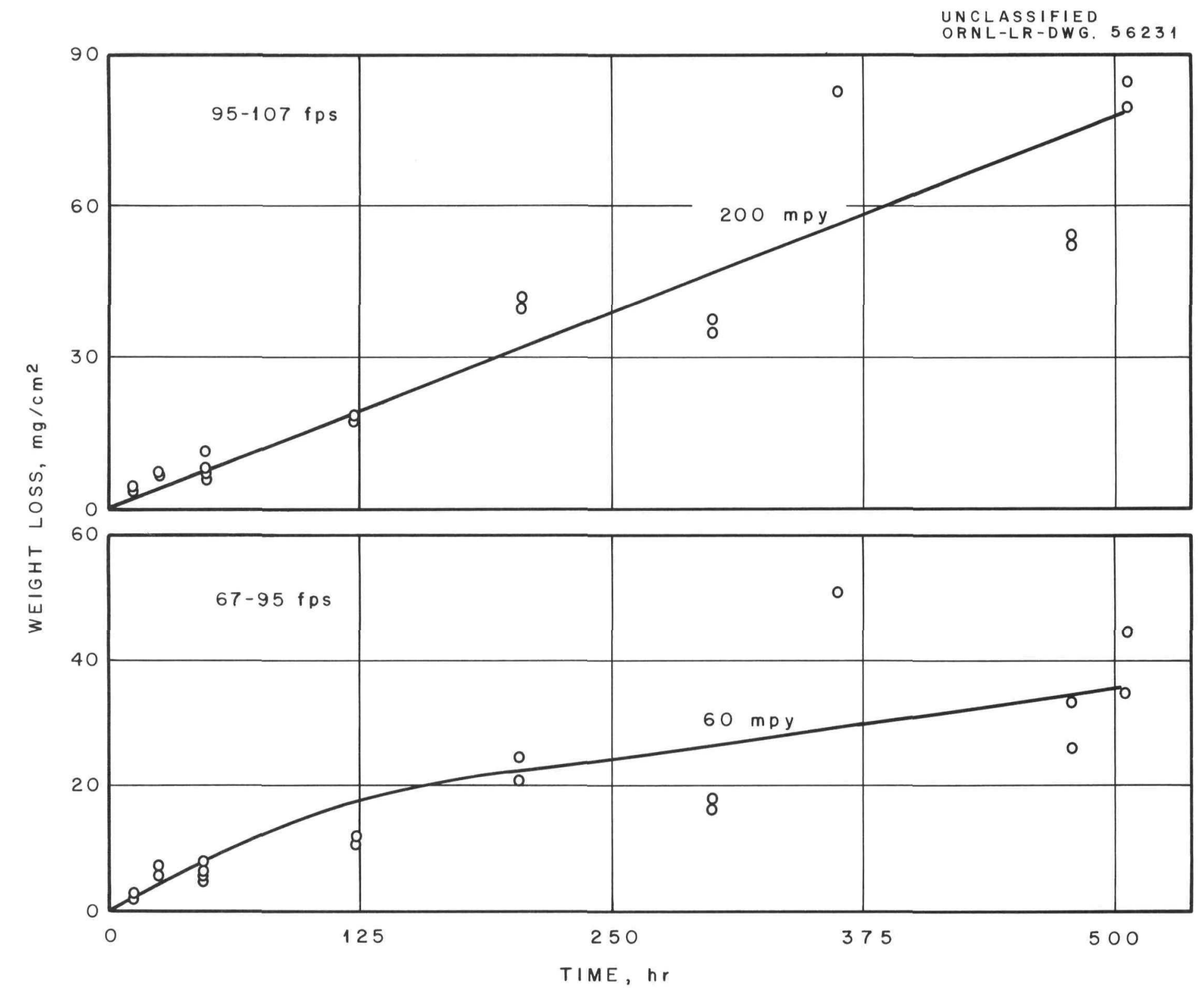

Fig. 11. The Corrosion of Type $\times 8001$ Aluminum in Water at $260^{\circ} \mathrm{C}$. 
Table 11. Effect of Time on the Corrosion of X8001 Aluminum Specimens by Flowing Water at $260^{\circ} \mathrm{C}$

\begin{tabular}{|c|c|c|c|}
\hline $\begin{array}{l}\text { Time } \\
(h r)\end{array}$ & $\begin{array}{l}\text { Velocity } \\
\text { Range } \\
\text { (fps) }\end{array}$ & $\begin{array}{c}\text { Weight } \\
\text { Loss } \\
\left(\mathrm{mg} / \mathrm{cm}^{2}\right)\end{array}$ & $\begin{array}{c}\text { Corrosion } \\
\text { Rate } \\
\text { (mpy) }\end{array}$ \\
\hline 13 & $\begin{array}{l}20-31 \\
31-44 \\
44-67 \\
67-95 \\
95-107\end{array}$ & $\begin{array}{ll}0.9, & 0.6 \\
0.7, & 0.6 \\
1.3, & 1.6 \\
2.9, & 2.6 \\
4.2, & 3.6\end{array}$ & $\begin{array}{rr}93, & 62 \\
77, & 62 \\
138, & 165 \\
309, & 275 \\
440, & 386\end{array}$ \\
\hline 25 & $\begin{array}{l}20-31 \\
31-44 \\
44-67 \\
67-95 \\
95-107\end{array}$ & $\begin{array}{ll}4.2, & 3.0 \\
4.6, & 4.3 \\
5.9, & 4.9 \\
6.9, & 7 \cdot 5 \\
7.7, & 7 \cdot 7\end{array}$ & $\begin{array}{l}225,161 \\
244,226 \\
314,258 \\
365,399 \\
406,406\end{array}$ \\
\hline 48 & $\begin{array}{l}20-31 \\
31-44 \\
44-67 \\
67-95 \\
95-107\end{array}$ & $\begin{array}{ll}3.2, & 2.1 \\
3.2, & 3.6 \\
4.0, & 4.2 \\
4.7, & 5.3 \\
6.7, & 6.1\end{array}$ & $\begin{array}{rr}85, & 56 \\
85, & 96 \\
105, & 112 \\
124, & 140 \\
178, & 162\end{array}$ \\
\hline 48 & $\begin{array}{l}20-31 \\
31-44 \\
44-67 \\
67-95 \\
95-107\end{array}$ & $\begin{array}{rr}4.0, & 4.7 \\
6.0, & 3.7 \\
5.8, & 6.1 \\
5.9, & 7.9 \\
11.4, & 8.3\end{array}$ & $\begin{array}{l}105,125 \\
158,98 \\
154,162 \\
156,210 \\
303,220\end{array}$ \\
\hline 123 & $\begin{array}{l}20-31 \\
31-44 \\
44-67 \\
67-95 \\
95-107\end{array}$ & $\begin{array}{rr}7.4, & 5.9 \\
5.9, & 6.8 \\
10.2, & 7.7 \\
11.8, & 11.1 \\
17.4, & 18.5\end{array}$ & $\begin{array}{rr}78, & 62 \\
62, & 72 \\
108, & 82 \\
125, & 117 \\
184, & 196\end{array}$ \\
\hline 204 & $\begin{array}{l}20-31 \\
31-44 \\
44-67 \\
67-95 \\
95-107\end{array}$ & $\begin{array}{l}14.4,9.6 \\
12.9,11.0 \\
15.4,12.3 \\
27.5,21.3 \\
42.2,40.6\end{array}$ & $\begin{array}{rr}89, & 60 \\
80, & 68 \\
96, & 76 \\
170, & 131 \\
262, & 252\end{array}$ \\
\hline 300 & $\begin{array}{l}20-31 \\
31-44 \\
44-67 \\
67-95 \\
95-107\end{array}$ & $\begin{array}{l}11.0,9.3 \\
10.5,10.0 \\
12.3,11.6 \\
18.0,16.6 \\
37.9,35.1\end{array}$ & $\begin{array}{rr}47, & 40 \\
45, & 43 \\
53, & 50 \\
77, & 71 \\
162, & 150\end{array}$ \\
\hline 360 & $\begin{array}{l}20-31 \\
31-44 \\
44-67 \\
67-95 \\
95-107\end{array}$ & $\begin{array}{l}14.3 \\
16.0 \\
27.3 \\
53.3 \\
83.9\end{array}$ & $\begin{array}{r}50 \\
57 \\
96 \\
188 \\
296\end{array}$ \\
\hline
\end{tabular}


Table 11 (continued)

\begin{tabular}{|c|c|c|c|}
\hline $\begin{array}{l}\text { Time } \\
\text { (hr) }\end{array}$ & $\begin{array}{l}\text { Velocity } \\
\text { Range } \\
\text { (fps) }\end{array}$ & $\begin{array}{c}\text { Weight } \\
\text { Loss } \\
\left(\mathrm{mg} / \mathrm{cm}^{2}\right)\end{array}$ & $\begin{array}{c}\text { Corrosion } \\
\text { Rate } \\
\text { (mpy) }\end{array}$ \\
\hline 478 & $\begin{array}{l}20-31 \\
31-44 \\
44-67 \\
67-95 \\
95-107\end{array}$ & $\begin{array}{l}14.5,10.3 \\
15.0,12.7 \\
17.5,14.8 \\
33.4,26.0 \\
54.2,52.5\end{array}$ & $\begin{array}{rr}38, & 27 \\
40, & 34 \\
46, & 39 \\
88, & 69 \\
143, & 139\end{array}$ \\
\hline 504 & $\begin{array}{l}20-31 \\
31-44 \\
44-67 \\
67-95 \\
95-107\end{array}$ & $\begin{array}{ll}12.7, & 11.0 \\
13.9, & 13.5 \\
19.3, & 16.2 \\
44.7, & 34.9 \\
85.0, & 80.7\end{array}$ & $\begin{array}{rr}32, & 28 \\
35, & 34 \\
48, & 41 \\
113, & 88 \\
215, & 204\end{array}$ \\
\hline
\end{tabular}

Effect of Surface Finish and Pretreatment. One loop run was made to determine the difference in corrosion rates among $\mathrm{X} 8001$ aluminum specimens in the "asmachined" condition, those metallographically polished, and those that had prior exposure to static, high-temperature water. The test was carried out for 10 days at $260^{\circ} \mathrm{C}$, and all specimens were from the same plate of X8001. Five specimens of each surface condition were exposed over the velocity range of 22 to 115 fps.

The "as-machined" specimens had a finish of $32 \mu \mathrm{in}$. rms or slightly less. The metallographic polishing was accomplished by hand-polishing successively with 320-, 400-, 600-, 0-, 00-, and 000-grit papers followed by wheel-polishing on diamond cloths having particle sizes of 30,6 , and less than $1.5 \mu$. Two different pretreatments were employed. In both cases, "as-machined" specimens were exposed to deionized water in autoclaves for a 24-hr period prior to exposure in the loop. In one case the pretreatment-water temperature was $250^{\circ} \mathrm{C}$ and in the other, $300^{\circ} \mathrm{C}$. Control specimens exposed in the same autoclaves indicated that an average of $0.04 \mathrm{mil}$ of aluminum was corroded during the pretreatment at $250^{\circ} \mathrm{C}$ and $0.09 \mathrm{mil}$ at $300^{\circ} \mathrm{C}$. This penetration was so small that it was ignored in determining the corrosion rates of the specimens at the end of the loop run.

Table 12 shows the corrosion rates of the specimens during the 10-day loop exposure at $260^{\circ} \mathrm{C}$. Also shown in the last column are the average rates observed for all X800I specimens exposed under the same conditions (taken from Table 7).

All specimens were subject to random pitting of 0.001 in. or less, and one pit $0.003 \mathrm{in}$. deep was found on one of the metallographically polished specimens. A comparison between the "as-machined" and metallographically polished specimens suggests that the polished specimens exhibited slightly lower corrosion rates. Actually the difference between the two is small and is possibly partly due to a difference in true surface area between the two sets of specimens. On the other hand, the pretreated specimens showed significantly lower corrosion rates than the untreated specimens at the lower flow rates. Those specimens pretreated at $250^{\circ} \mathrm{C}$ exhibited corrosion rates only about half as high as those tested in the "as-machined" condition up to $47 \mathrm{fps}$. Those treated at $300^{\circ} \mathrm{C}$ had rates only about one third as high as the "as-machined" specimens at flow rates up to $47 \mathrm{fps}$. At higher flow rates the pretreatment appeared to be of little value. 
Table 12. The Effect of Surface Condition and Pretreatment on the Corrosion of X8001 Aluminum in Water at $260^{\circ} \mathrm{C}$ During a 10 -Day Test

\begin{tabular}{|c|c|c|c|c|c|}
\hline \multirow{2}{*}{$\begin{array}{l}\text { Velocity } \\
\text { Range } \\
\text { (fps) }\end{array}$} & \multicolumn{5}{|c|}{ Corrosion Rate (mpy) } \\
\hline & As-Machined & Polished & $\frac{\text { Pretr }}{250^{\circ} \mathrm{C}}$ & $\frac{\operatorname{ated*}}{300^{\circ} \mathrm{C}}$ & $\begin{array}{c}\text { Average } \\
\text { As-Machined** }\end{array}$ \\
\hline $22-33$ & 57 & 44 & 33 & 18 & 61 \\
\hline $33-47$ & 56 & 48 & 33 & 18 & 53 \\
\hline $47-73$ & 105 & 52 & 62 & 41 & 69 \\
\hline $73-102$ & 166 & 103 & 128 & 91 & 149 \\
\hline $102-115$ & 322 & 230 & 211 & 225 & 328 \\
\hline
\end{tabular}

*Pretreated in static deionized water for $24 \mathrm{hr}$.

**Average of all X8001 specimens exposed in the "as-machined" condition at $260^{\circ} \mathrm{C}$ (taken from Table 7 ).

The Corrosion Rate of Experimental Alloys. Seven experimental alloys supplied by the Aluminum Company of America in addition to X8001 were tested in highpurity circulating water at $260^{\circ} \mathrm{C}$ for 10 -day periods. Table 13 shows the alloy designations and chemical compositions. Except for alloy X2219, all contained nickel and iron, and some contained very low silicon contents.

Table 13. The Chemical Composition of Experimental Aluminum Alloys

\begin{tabular}{lcrrrrrc}
\hline & \multicolumn{7}{c}{ Chemical Composition (\%) } \\
\cline { 2 - 7 } & Fe & Ni & Si & Cu & Zn & Ti & Al \\
\hline X8001 & 0.43 & 0.84 & 0.04 & 0.02 & & & Balance \\
X8002 & 1.43 & 1.42 & 0.05 & $<0.02$ & $<0.02$ & & Balance \\
192598 & 0.40 & 2.90 & $<0.01$ & $<0.02$ & $<0.02$ & & Balance \\
228678 & 1.50 & 1.40 & 0.01 & 0.02 & 0.02 & & Balance \\
192597 & 1.54 & 1.42 & 0.04 & $<0.02$ & 0.02 & & Balance \\
225053 & 0.50 & 1.00 & $<0.01$ & $<0.02$ & $<0.02$ & & Balance \\
192263 & 1.44 & 1.38 & 0.08 & 0.03 & 0.02 & 0.02 & Balance \\
X2219* & 0.21 & & 0.10 & 5.87 & & 0.09 & Balance \\
\hline
\end{tabular}

*Contained also $0.28 \% \mathrm{Mn}, 0.10 \% \mathrm{~V}$, and $0.17 \% \mathrm{Zr}$.

Specimens of all the alloys except X2219 were exposed in the same loop run. These alloys were received in the form of l/16-in.-thick sheet from which the specimens were cut. The specimens were tested in the "as-rolled" condition; only cleaning in acetone and water was employed prior to test. As with all tests, the specimens were insulated from the holder and each other with Teflon tape. 
For this test two straight-channel specimen holders were used. The specimen dimensions were the same as in the other tests except for the thickness. The flow rate of the water past the specimens was $42 \mathrm{fps}$. Since the first specimen in a holder occasionally shows greater attack than the other specimens, type X8001 specimens were placed in the first position of each holder. Three specimens of each of the other alloys filled the remaining 18 positions in the holders.

Table 14 shows the observed corrosion rates. The results show that all specimens, regardless of composition, corroded at practically the same rate during the test with the exception of the X8001 specimens which showed slightly higher rates, possibly because of their location in the holder. There was no evidence of subsurface attack as was observed with 1100, 5154, and 6061 aluminum alloys exposed under the same conditions. A comparison of the rates for the experimental alloys with those shown in Table 7 for $X 8001$ aluminum in the same velocity range indicates no major difference between X8001 and the group of experimental alloys. In addition the quantity of corrosion products retained on the surface of the specimens was approximately the same as was retained by the X8001 specimens exposed at the same flow rate at $260^{\circ} \mathrm{C}$.

Table 14. The Corrosion Rates of Experimental Aluminum Alloys in water at $260^{\circ} \mathrm{C}$

(Test time, 10 days; water flow rate, 42 fps)

\begin{tabular}{|c|c|c|}
\hline $\begin{array}{c}\text { Alloy } \\
\text { Identification }\end{array}$ & $\begin{array}{l}\text { Specimen } \\
\text { Number }\end{array}$ & $\begin{array}{c}\text { Corrosion Rate } \\
\text { (mpy) }\end{array}$ \\
\hline$X 8001$ & $\begin{array}{l}1 \\
2\end{array}$ & $\begin{array}{l}95 \\
91\end{array}$ \\
\hline 225059 & $\begin{array}{l}1 \\
2 \\
3\end{array}$ & $\begin{array}{l}72 \\
67 \\
70\end{array}$ \\
\hline 192598 & $\begin{array}{l}1 \\
2 \\
3\end{array}$ & $\begin{array}{l}71 \\
65 \\
70\end{array}$ \\
\hline 228678 & $\begin{array}{l}1 \\
2 \\
3\end{array}$ & $\begin{array}{l}73 \\
67 \\
67\end{array}$ \\
\hline 192597 & $\begin{array}{l}1 \\
2 \\
3\end{array}$ & $\begin{array}{l}67 \\
71 \\
70\end{array}$ \\
\hline 225053 & $\begin{array}{l}1 \\
2 \\
3\end{array}$ & $\begin{array}{l}73 \\
71 \\
68\end{array}$ \\
\hline 192263 & $\begin{array}{l}1 \\
2 \\
3\end{array}$ & $\begin{array}{l}68 \\
59 \\
63\end{array}$ \\
\hline
\end{tabular}


Specimens of aluminum alloy X2219 were tested in two separate 10-day loop runs at $260^{\circ} \mathrm{C}$. For both tests specimen holders with tapered channels were used. Table 15 shows the observed corrosion rates which are very similar to those observed with X800I specimens tested under the same conditions. There was a small number of shallow pits on the surface of the specimens, but no subsurface attack was detectable.

Table 15. The Corrosion Rate of X2219 Aluminum in Water at $260^{\circ} \mathrm{C}$ During 10 -Day Tests

\begin{tabular}{crr}
\hline $\begin{array}{c}\text { Velocity Range } \\
\text { (fps) }\end{array}$ & $\begin{array}{c}\text { Corrosion Rate } \\
\text { (mpy) }\end{array}$ \\
\hline $20-31$ & 110 & 48 \\
$31-44$ & 58 & 36 \\
$44-67$ & 79 & 67 \\
$67-95$ & 188 & 195 \\
$95-107$ & 313 & 320 \\
\hline
\end{tabular}

The results obtained with the experimental alloys indicate that they have comparable but no greater corrosion resistance than $\mathrm{X} 8001$ under the conditions of test. This conclusion agrees with that reached by Whatley ${ }^{15}$ as a result of tests conducted with the same and similar alloys at $260^{\circ} \mathrm{C}$ and at 20 fps for considerably longer periods of time. Since all of these alloys, including X8001, contain a second phase, it appears that certain types of a second phase uniformly distributed in the alloy are beneficial to the corrosion resistance of aluminum; however, all additions that result in the formation of a second phase are not beneficial, as previously shown. ${ }^{3}$

\section{SUMMARY}

The major results obtained from the work described in this report can be summarized as follows:

1. During 10-day tests in the temperature range of 170 to $200^{\circ} \mathrm{C}, 1100,5154$, 6061 , and $\mathrm{X} 8001$ aluminum alloys exhibited essentially the same corrosion behavior. In the velocity range of 20 to 107 fps, corrosion rates were generally higher, the higher the velocity.

2. At $230^{\circ} \mathrm{C}, 1100$ and $x 8001$ aluminum alloys (the only alloys tested at this temperature) behaved alike, and at 20 to $67 \mathrm{fps}$ the corrosion rates of these alloys were nearly the same as observed at 170 and $200^{\circ} \mathrm{C}$. At all temperatures up to and including $230^{\circ} \mathrm{C}$, none of the alloys showed localized attack except for occasional shallow pits.

3. At $260^{\circ} \mathrm{C}$ many of the 1100 and 6061 aluminum specimens underwent significant localized attack in the form of subsurface void formation, whereas others showed no sign of this type of attack. It appeared that had the tests lasted. longer than 10 days all specimens of these alloys would have been seriously damaged by this type of attack. On the other hand, specimens of X8001 aluminum were completely free of localized attack except for a few shallow pits. The corrosion rate of X8001 specimens was nearly independent of flow rate between 20 and 67 fps. 
4. Of the commercially available alloys tested, only X8001 did not suffer catastrophic attack at $290^{\circ} \mathrm{C}$. In fact, at the three highest velocities the corrosion rate of $\mathrm{X} 800 \mathrm{I}$ aluminum appeared to be slightly lower at $290^{\circ} \mathrm{C}$ than at $260^{\circ} \mathrm{C}$.

5. At $260^{\circ} \mathrm{C}$, $\mathrm{X} 800 \mathrm{I}$ aluminum corroded fairly rapidly during the first 100 to $200 \mathrm{hr}$ of test and then proceeded to corrode at lower constant rates in the range of 20 to $95 \mathrm{fps}$; at the highest velocity tested, the corrosion rate was constant. The observed linear corrosion rates after the initial 100-to 200-hr period were: 5 mpy at 20 to 31 fps; 10 mpy at 31 to 44 fps; 15 mpy at 44 to $67 \mathrm{fps}$; 60 mpy at 67 to $95 \mathrm{fps}$; and $200 \mathrm{mpy}$ at 95 to $107 \mathrm{fps}$.

6. Highly polished specimens of X800I aluminum corroded at approximately the same rate in water at $260^{\circ} \mathrm{C}$ as specimens with a machined finish, but specimens pretreated in water at 250 or $300^{\circ} \mathrm{C}$ for $24 \mathrm{hr}$ in an autoclave were significantly more resistant to attack in water flowing at 20 to $47 \mathrm{fps}$ than were the "as-machined" specimens; at higher flow rates the pretreatment was not effective.

7. Several experimental alloys containing various concentrations of iron, nickel, and silicon appeared to be no more resistant to attack at $260^{\circ} \mathrm{C}$ and $42 \mathrm{fps}$ than did the X8001 alloy.

8. Based on the observed corrosion rate and the fact that the HFIR fuel elements will be in the reactor only 10 days, any of the alloys tested could be used as cladding so long as the average temperature of the oxide film (i.e., the temperature that controls the rate of corrosion under conditions of heat flux) did not exceed $230^{\circ} \mathrm{C}$ and the flow rate of the coolant was less than $65 \mathrm{fps}$. At higher temperatures only the X8001 alloy and the experimental alloys could be used. Regardless of temperature it seems that none of the alloys could be used successfully at $100 \mathrm{fps}$ in view of the high corrosion rate and the thinness of fuel-element claddings.

\section{ACKINOWLEDGMENT}

The authors wish to acknowledge M. T. Kegley, who performed the metallographic examination of the specimens.

\section{REF'ERENCES}

1. J. E. Draley and W. E. Ruther, "Aqueous Corrosion of Aluminum, Part I," Corrosion 12, 441t-448t (1956).

2. P. O. Strom and M. H. Boyer, Static Corrosion of Aluminum Alloys at $350^{\circ} \mathrm{F}$ and $480^{\circ} \mathrm{F}$ in Distilled Water, LRL-64 (Oct. 1953).

3. M. H. Brown, R. H. Brown, and W. W. Binger, Aluminum Alloys for Handling High-Temperature Water, paper presented at the Sixteenth Annual Conference, National Association of Corrosion Engineers, Dallas, Texas, March 14-18, 1960.

4. J. E. Draley and W. E. Ruther, "Aqueous Corrosion of Aluminum, Part II," Corrosion 12, 480t-490t (1956).

5. J. E. Draley, Aqueous Corrosion of 1100 Aluminum and of Aluminum-Nickel Alloys, paper presented at the International Conference on Aqueous Corrosion of Reactor Materials, Brussels, Oct. 14-16, 1959.

6. J. E. Draley, private communication. 
7. J. A. Lane, High-Flux Isotope Reactor, Preliminary Design Study, ORNL CF-59-2-65 (Mar. 20, 1959).

8. T. E. Cole, High-Flux Isotope Reactor, A General Description, ORNL $\mathrm{CF}-60-3-33(\overline{\mathrm{Mar} .} 15,1960)$.

9. D. R. DeHalas, A Study of Heat-Transfer Effects on Aluminum Corrosion, Part I, HW-42585 Rev. (Apr. 19, 1956).

10. R. J. Lobsinger and J. M. Atwood, "Corrosion of Aluminum in High-Purity Water," Corrosion 13, 582t-584t (1957).

11. J. C. Griess, H. C. Savage et al., Effect of Heat Flux on the Corrosion of Aluminum by Water. Part I. Experimental Equipment and Preliminary Results, ORNL-2939 (Apr. 29, 1960).

12. J. C. Griess, H. C. Savage et al., Effect of Heat Flux on the Corrosion of Aluminum by Water. Part II. Influence of Water Temperature, Velocity, and pH on Corrosion-Product Formation, ORNL-3056 (Feb. 10, 1961).

13. J. A. Lane, H. G. MacPherson, and F. Maslin, Eds., Fluid Fuel Reactors, p 201-202, Addison-Wesley, Reading, Mass., 1958.

14. M. D. Ferrier, Minutes of a Conference on the Corrosion of Aluminum in Water at High Temperature Held at Chalk River, Ontario, Dec. 18-19, 1956, CRMet-700 (June 1957).

15. V. Whatley, Aqueous Corrosion of Aluminum at $260^{\circ} \mathrm{C}, \mathrm{DP}-521$ (Oct. 1960). 


\author{
ORNL-3063 \\ UC-25 - Metals, Ceramics, \\ and Materials \\ TID-4500 (16th ed.)
}

\title{
INTERINAL DISTRIBUTION
}

1. Biology Library

2-3. Central Research Library

4. Reactor Division Library

5. ORIL - Y-12 Technical Library, Document Reference Section

6-25. Laboratory Records Department

26. Laboratory Records, ORNL R.C.

27. G. M. Adamson

28. A. I. Bacarella

29. J. E. Baker

30. J. M. Baker

31. R. D. Baybarz

32. R. J. Beaver

33. E. C. Bohlmann

34. E. S. Bomar

35. R. D. Bundy

36. C. E. Center

37. T. G. Chapman

38. R. A. Charpie

39. A. Chetham-Strode

40. R. D. Cheverton

41. H. C. Claiborne

42. R. S. Cockreham

43. Esther Cohn

44. T. E. Cole

45. C. W. Collins

46. E. I. Compere

47. F. W. Cooke

48. F. I. Culler

49. J. E. Cunningham

50. R. J. Davis

51. J. I. English

52. J. H. Erwin

53. D. E. Ferguson

54. J. Foster

55. W. R. Gall

56. W. R. Gambill

57. J. P. Gill

58-67. J. C. Griess

68. H. Grimac

69. W. R. Grimes

70. I. A. Haack

71. J. P. Hammond

72. D. N. Hess

73. N. Hilvety

74. A. Hollaender

75. A. S. Householder

76. G. H. Jenks

77. D. T. Jones

78. R. G. Jordan $(Y-12)$

79. W. H. Jordan
80. P. R. Kasten

81. T. M. Kegley

82. C. P. Keim

83. M. T. Kelley

84. J. A. Lane

85. R. E. Leuze

86. T. A. Lincoln

87. S. C. Lind

88. R. S. Livingston

89. R. A. Lorenz

90. R. N. Lyon

91. D. W. Magnus on

92. T. H. Mauney

93. R. V. McCord

94. H. F. McDuffie

95. H. A. McLain

96. J. A. McWherter

97. K. Z. Morgan

98. J. P. Murray (K-25)

99. M. L. Nelson

100. P. D. Newmann

101. I. C. Oakes

102. P. Patriarca

103. D. Phillips

104. S. A. Reed

105. P. M. Reyling

106. L. Rice

107. G. Samuels

108. H. C. Savage

109. H. W. Savage

110. R. E. Schappel

111. H. E. Seagren

112. E. D. Shipley

113. A. J. Shor

114. M. J. Skinner

115. A. H. Snell

116. I. Spiewak

117. J. A. Swartout

118. A. Taboada

119. J. W. Tackett

120. E. H. Taylor

121. M. Tobias

122. D. R. Vondy

123. G. M. Watson

124. A. M. Weinberg:

125. C. E. Winters

126. I. F. Woo

127. F. Daniels (consultant)

128. F. T. Gucker (consultant)

129. F. T. Miles (consultant) 
$-30-$

FXTERIVAL DISTRIBUTION

130. Division of Research and Development, AEC, ORO

131-707. Given distribution as shown in TID-4500 (16th ed.) under Metals, Ceramics, and Materials ( 75 copies - OTs) 